\title{
Corrosion of Lead Shielding in Model 9975 Package (U)
}

\author{
K. H. Subramanian
}

Savannah River National Laboratory Strategic Materials Technology Department

Materials Technology Section

Publication Date: March 2006

Westinghouse Savannah River Company

Savannah River Site

Aiken, SC 29808

This document was prepared in connection with work done under Contract No. DE-AC09-96SR18500 with the U. S. Department of Energy 
WSRC-TR-2006-00094

\section{DISCLAIMER}

This report was prepared as an account of work sponsored by an agency of the United States Government. Neither the United States Government nor any agency thereof, nor any of their employees, makes any warranty, express or implied, or assumes any legal liability or responsibility for the accuracy, completeness, or usefulness of any information, apparatus, product, or process disclosed, or represents that its use would not infringe privately owned rights. Reference herein to any specific commercial product, process, or service by trade name, trademark, manufacturer, or otherwise does not necessarily constitute or imply its endorsement, recommendation, or favoring by the United States Government or any agency thereof. The views and opinions of authors expressed herein do not necessarily state or reflect those of the United States Government or any agency thereof. 


\section{APPROVALS}

$\bar{K}$. H. Subramanian, Author

$$
\text { Date: } 4 / 30 / 06
$$
Materials Performance and Corrosion Technology Materials Science and Technology Directorate

P. E. Zapp/Technical Reviewer

$$
\text { Date: } 5-2-06
$$
Materials Performance and Corrosion Technology Materials Science and Technology Directorate

Date: $5-2-06$

K! A. Duthn, Pu Surveillance Program Lead Materials Performance and Corrosion Technology

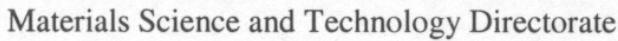

G. T. Chandler, Manager

Date: $5-2-06$

Materials Performance and Corrosion Technology

Materials Science and Technology Directorate

N. C. Iyer, Manager

$$
\text { Jate: } 5-2-06
$$

Materials Science and Technology Directorate Savannah River National Laboratory
J.A Murphy, Design Authority

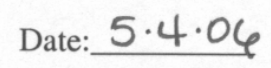
Transportation Services

Technical and Quality Services

J.S. Bellarify, 9975 Design Agent

Date: $5 / 6 / 06$

Savannah River Packaging Technology

Engineered Equipment and Systems 


\section{Table of Contents}

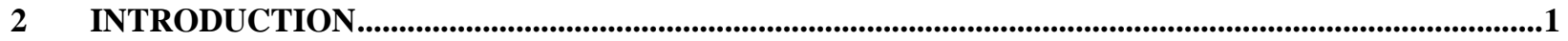

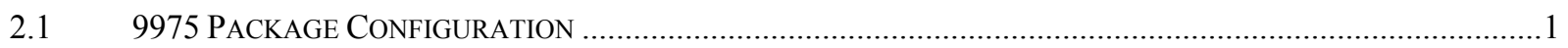

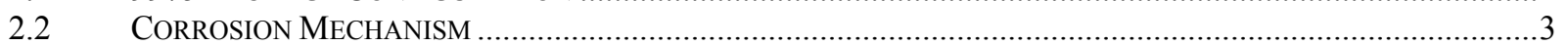

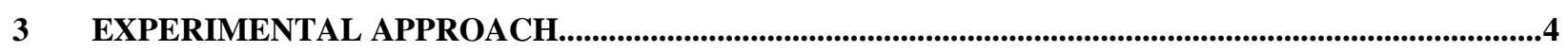

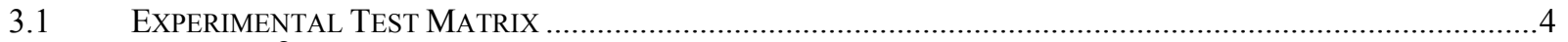

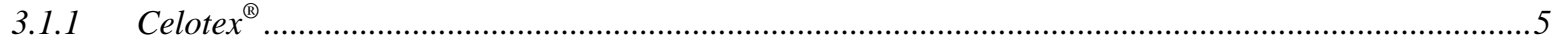

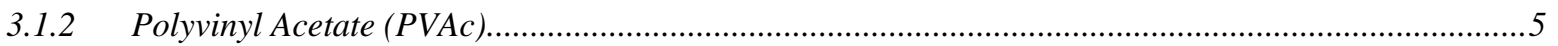

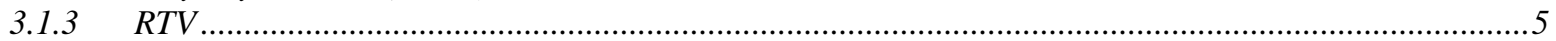

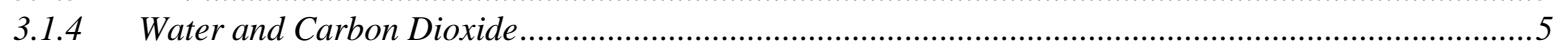

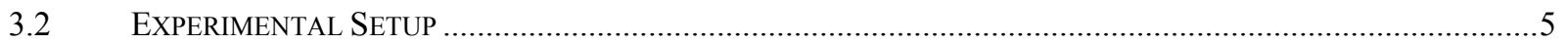

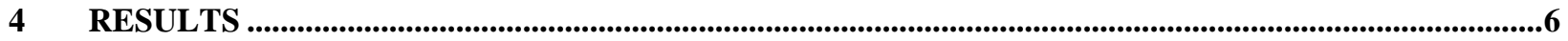

4.1 Corrosion Rate ANALYSIS FOR THE COUPONS EXPOSED In CONDENSED WATER CELlS ........................7

4.2 CORRosion RATE ANALYSIS FOR THE COUPONS EXPOSED IN AMBIENT HuMidity CELLS ........................11

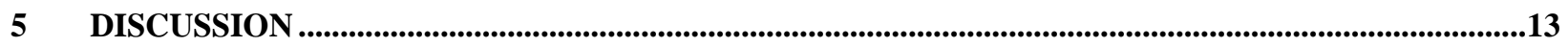

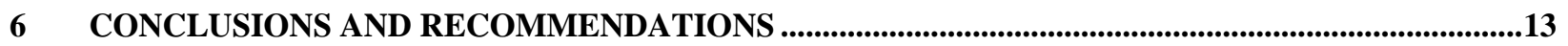

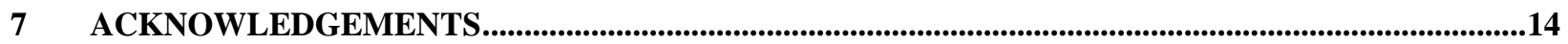

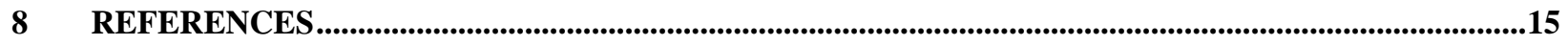

APPENDIX A: COUPONS AFTER 30 DAY EXPOSURE. …............................................................................

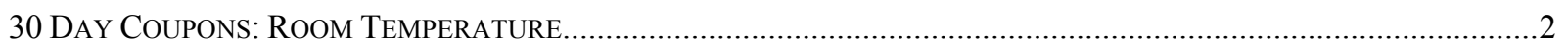

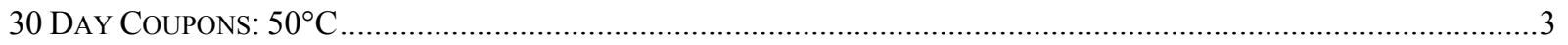

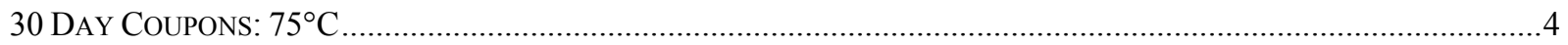

APPENDIX B: COUPONS AFTER EXPOSURE AFTER 75 DAY EXPOSURE. ................................................6

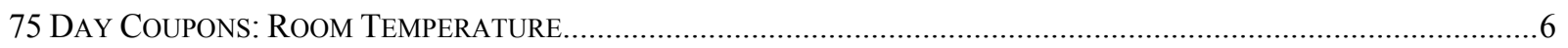

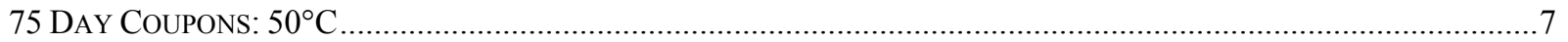

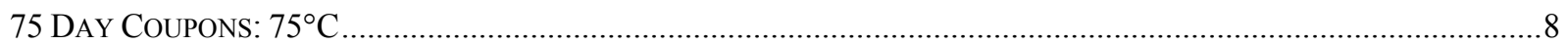

APPENDIX C: COUPONS AFTER 120 DAY EXPOSURE. .............................................................................10

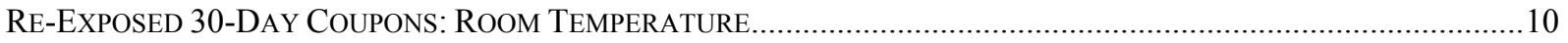

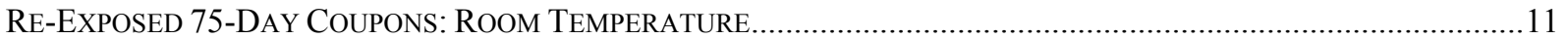

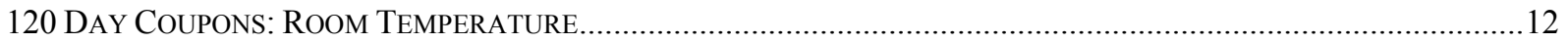

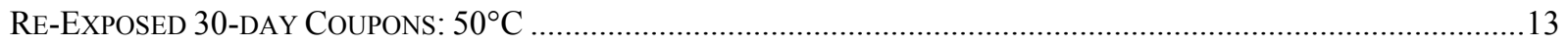

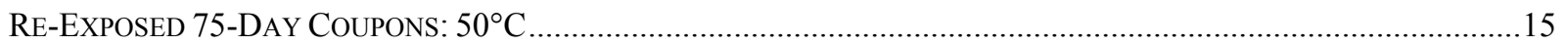

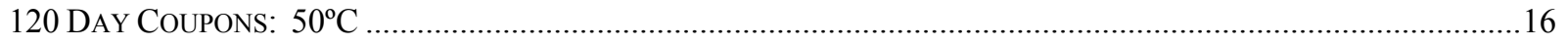

RE-EXPOSED 30 DAY CO

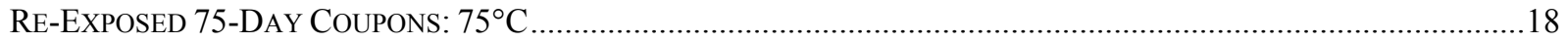

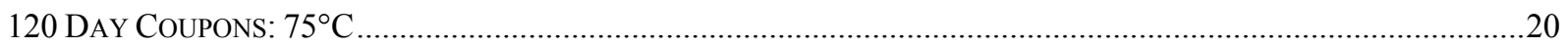




\section{List of Tables}

TABle 1: PRimary MATERIALs OF CONSTRUCTION OF 9975 PACKAGE .2

TABle 2: Select Properties of LEAd, Lead CARBonate, AND BASIC LEAD CARbonate[9] ..................................

TABLE 3: SUMMARY OF DisCRETE VARIABLES IN PARAMETRIC TEST MATRIX

\section{List of Figures}

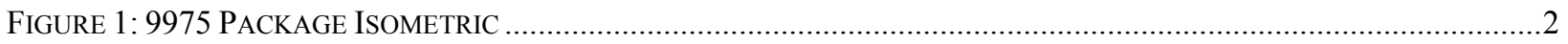

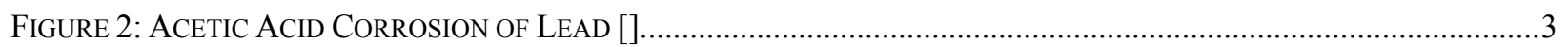

Figure 3: SCHEMATIC OF ATMOSPHERIC LEAD CORRosion DUE TO ACETIC ACID.[10].............................................

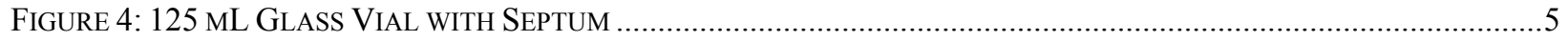

FIGURE 5: PERFORATED BASE STUD TO BE USED AS COUPON RACK.........................................................................6

FIGURE 6: NOMINAL LEAD SAMPLE (OD = 1.5-IN., ID - 0.312 IN.) .....................................................................6

Figure 7: CORROSION RATES FOR LEAD COUPONS EXPOSED TO CONDENSED WATER CELLS AT ROOM TEMPERATURE

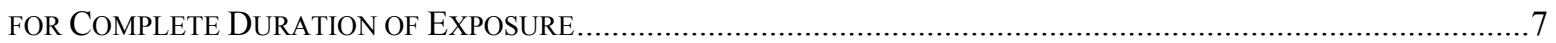

Figure 8: CORROSION RATES FOR LEAD COUPONS TO CONDENSED WATER CELlS AT $50^{\circ} \mathrm{C}$ FOR COMPLETE

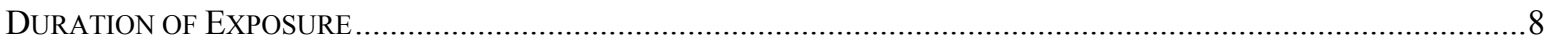

Figure 9: CORRosion RATES For LEAd COUPONS EXPOSED to CONDENSED WATER CELlS AT $75^{\circ} \mathrm{C}$ FOR COMPLETE

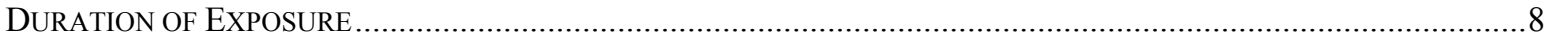

FiguRE 10: CORROSION RATES FOR LEAD COUPONS EXPOSED TO CONDENSED WATER CELLS AT ROOM TEMPERATURE FOR RE-EXPOSED COUPONS AND 120-DAY COUPONS .................................................................9

Figure 11: CORROSION RATES FOR LEAD COUPONS EXPOSED TO CONDENSED WATER CELlS AT $50^{\circ} \mathrm{C}$ FOR RE-

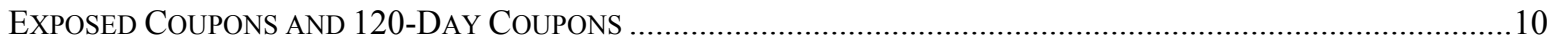

FIGURE 12: CORROSION RATES FOR LEAD COUPONS EXPOSED TO CONDENSED WATER CELLS AT $75^{\circ} \mathrm{C}$ FOR RE-

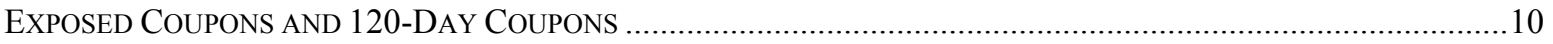

Figure 13: CORROSION RATES FOR LEAD COUPONS EXPOSED TO AMBIENT HUMIDITY CELLS AT ROOM TEMPERATURE FOR RE-EXPOSED COUPONS AND 120-DAY COUPONS ..................................................................11

FIGURE 14: CORROSION RATES FOR LEAD COUPONS EXPOSED TO CONDENSED WATER CELLS AT $50^{\circ} \mathrm{C}$ FOR RE-

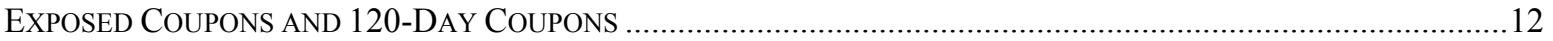

Figure 15: CORROSION RATES FOR LEAD COUPONS EXPOSED TO CONDENSED WATER CELLS AT $75^{\circ} \mathrm{C}$ FOR RE-

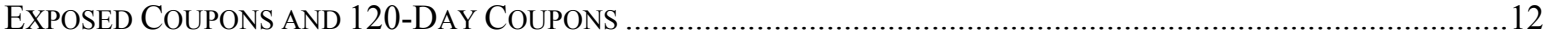




\section{SUMMARY}

Experiments were performed to determine the corrosion rate of lead when exposed to off-gas or degradation products of organic materials used in the model 9975 package.[1] The experiments were completed within the framework of a parametric test matrix with variables of organic configuration, temperature, humidity and the effect of durations of exposure on the corrosion of lead in the 9975 package. The room temperature vulcanizing (RTV) sealant was the most corrosive organic species in the testing, followed by the polyvinyl acetate (PVAc) glue. The Celotex@ material uniquely induced measurable corrosion only in situations with condensed water, and to a much lesser extent than the PVAc glue and RTV. The coupons exhibited faster corrosion at higher temperatures than at room temperatures. There was a particularly pronounced effect of condensed water as the coupons exposed in the cells with condensed water exhibited much higher corrosion rates.

In the 9975 package, the PVAc glue was determined to be the most aggressive due to it's proximity in the design. The condition considered most representative of the package conditions is that of the coupon exposed to the Celotex $\%$ glue organic exposed in the ambient humidity conditions. The corrosion rate of 2 mpy measured in the laboratory experiments for this condition is considered to be a bounding condition to the 9975 package conditions when the laboratory results are extrapolated to actual package conditions, and is recommended as a conservative estimate for package performance calculations.

\section{INTRODUCTION}

The Department of Transportation (DOT) requires the use of a Type B package for shipping materials containing more than 0.005 curies of plutonium. The Department of Energy (DOE) model 9975 package is a certified Type B package. The Savannah River Site (SRS) has further approved the 9975 package for storage of plutonium materials in K-Area Materials Storage (KAMS). Several 9975 packages inspected as part of their annual maintenance revealed a white coating on the exterior surface of the lead shielding.[2] An analysis of lead shielding in the model 9975 package hypothesized the corrosion was most likely due to acetic acid emissions from organic materials used in the 9975 package.[3] The organic materials include Celotex ${ }^{\circledR}$, polyvinyl acetate (PVAc) wood glue, and room temperature vulcanizing (RTV) sealant.

Several key data are necessary for the verification of the corrosion hypothesis and to determine the path forward and the short-term and long-term impact of the lead shielding corrosion on the performance of the 9975 package. These key data include the corrosion rate of lead when exposed to an environment similar to that of a 9975 package. These exposure experiments have been conducted and the results are presented here. These results will determine the impact of the degradation of the insulation assembly on the lead shielding corrosion and provide information for further analysis in terms of package integrity. The results of the testing are reported herein.

\section{$2.1 \quad 9975$ Package Configuration}

The 9975 package design includes two stainless steel containment vessels designed and fabricated in accordance with Section III of the ASME Boiler \& Pressure Vessel Code.[4] The 9975 package design also includes a lead shield to lower the package surface dose rate. The 9975 package is shown in Figure 1 with the materials of construction for each of the major features listed in Table 1. 
WSRC-TR-2006-00094

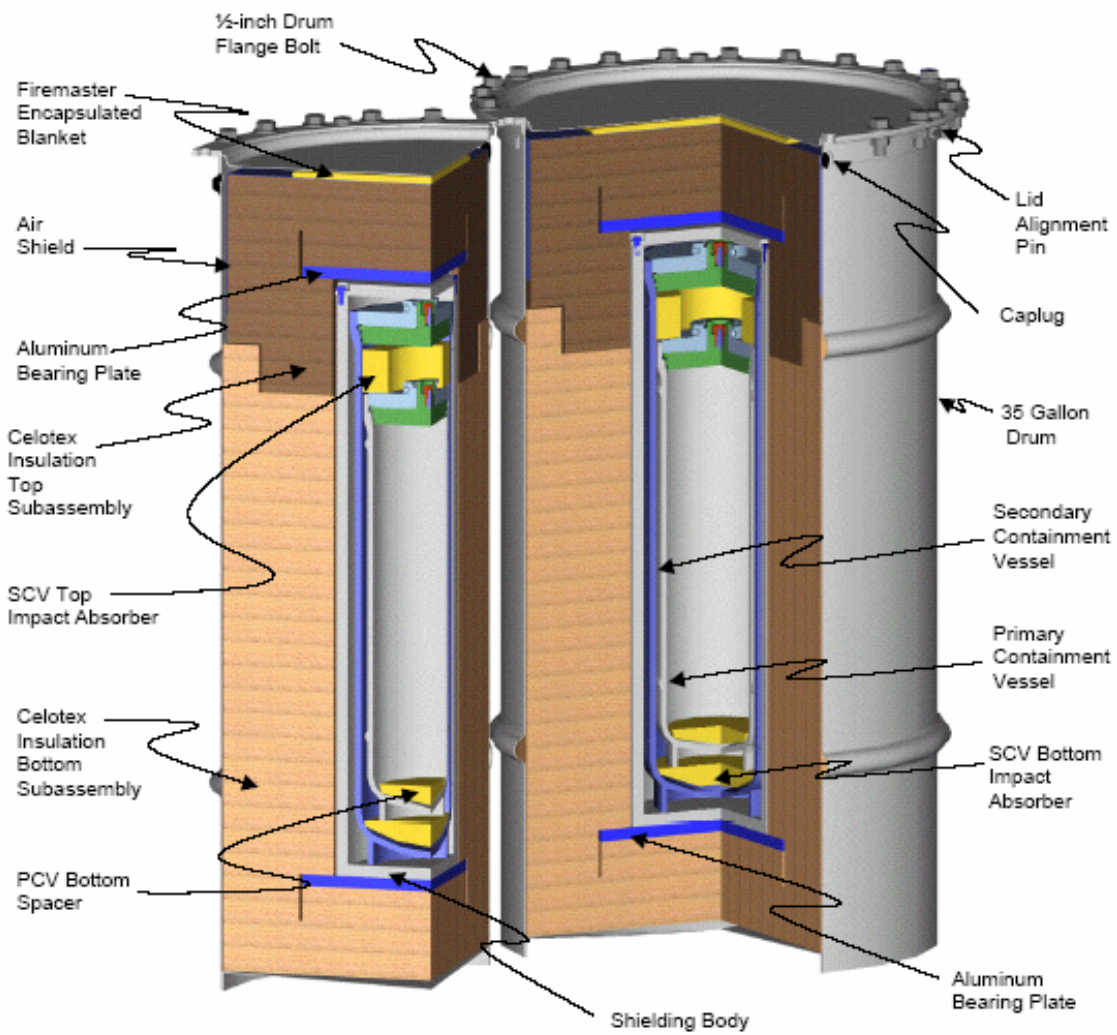

Figure 1: 9975 Package Isometric

The primary containment vessel (PCV), secondary containment vessel (SCV), and the outer drum are made of 304Lstainless steel. The containment vessels are encased in lead shielding which is encased in Celotex ${ }^{\circledR} /$ PVAc laminate comprised of the top and bottom sub-assemblies. The Celotex ${ }^{\circledR}$ brand name applies to cane fiberboard in this case. The Celotex ${ }^{\circledR}$ provides two safety functions: thermal insulation to limit PCV/SCV temperature during a fire, and mechanical resistance to package crushing. The Celotex ${ }^{\circledR}$ material used in 9975 packages is cane fiberboard insulation per ASTM C208-95, Grade IV wall sheathing. Layers of Celotex ${ }^{\circledR}$ are laminated together with an Elmer's ${ }^{\circledR}$ Professional Carpenters wood glue E690, a water-based polyvinyl acetate (PVAc) adhesive. Celotex ${ }^{\circledR}$ is composed of cellulose $(\leq 96 \%)$, starch $(\leq 10 \%)$, clay $(\leq 2 \%)$, carbon black $(<0.5 \%)$, paraffin wax binder $(\leq 2 \%)$ and a lamination adhesive $(\leq 3.5 \%)$. [5] The air shield is attached to the Celotex ${ }^{\circledR}$ insulation sub-assembly with a silicone rubber sealant, Dow-Corning 732-RTV.

Table 1: Primary Materials of Construction of 9975 Package

\begin{tabular}{ccc} 
Component & Material & Drawing Reference \\
\cline { 2 - 3 } Drum & Stainless Steel 304L & R-R2-F-0025 \\
Insulation & Celotex $^{\circledR}$ cane fiberboard & R-R2-F-0019 \\
Shielding & ASTM B749 Lead & R-R2-F-0020 \\
Shield Liner & Stainless Steel 304 & R-R2-F-0020 \\
Secondary Containment Vessel (SCV) & Stainless Steel 304L & R-R2-F-0016 \\
Primary Containment Vessel (PCV) & Stainless Steel 304L & R-R2-F-0016
\end{tabular}

The Celotex ${ }^{\circledR} /$ PVAc laminate is layered axially within the stainless drum. In this orientation, the outer surface of the lead cylinder is exposed to the laminate edge. The top of the lead shielding body is an aluminum lid which contacts the aluminum bearing plate in the top insulation sub-assembly. 


\subsection{Corrosion Mechanism}

Lead is highly resistant to corrosion in many environments due to the insolubility and self-healing nature of its primary protective film, $\mathrm{PbO}$. However, lead is susceptible to corrosion in the presence of acids and bases under specific conditions, such as exposure to organic acids, including acetic, chloroacetic, oxalic acid, and formic acid.[6] In this case, acetic acid is the specific corrodant of interest, since the cellulosic organic materials can off-gas acetic acid due to degradation.

A schematic of the corrosion process of lead when exposed to acetic acid is shown in Figure 2. Acetic acid catalyzes with lead to produce lead acetate and lead hydroxide, which in turn react with carbon dioxide to form lead carbonate. Lead carbonate then releases acetic acid and the process becomes self-sustaining.[7]

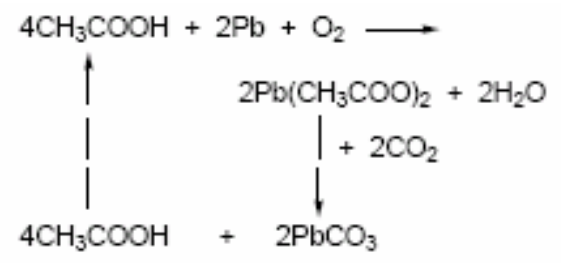

Figure 2: Acetic Acid Corrosion of Lead [8]

Using the data shown in Table 2, it was calculated that for 1 mil of lead carbonate, approximately 0.45 mils of lead is lost, and for 1 mil of basic lead carbonate, 0.4 mils of lead is lost.

Table 2: Select Properties of Lead, Lead Carbonate, and Basic Lead Carbonate[9]

\begin{tabular}{|c|c|c|c|}
\hline & Lead & $\begin{array}{c}\text { Lead Carbonate } \\
\text { (cerrusite) }\end{array}$ & $\begin{array}{c}\text { Basic Lead Carbonate } \\
\text { (hydrocerrusite) }\end{array}$ \\
\hline Chemical Symbol & $\mathrm{Pb}$ & $\mathrm{PbCO}_{3}$ & $\mathrm{~Pb}_{3}\left(\mathrm{CO}_{3}\right)_{2}(\mathrm{OH})_{2}$ \\
\hline Molecular Weight $\mathbf{( g / m o l )}$ & 207.2 & 267.2 & 775.6 \\
\hline Density (g/cm $\left.{ }^{3}\right)$ & 11.34 & 6.6 & 6.14 \\
\hline $\begin{array}{c}\text { Moles lead consumed per mole } \\
\text { of carbonate product }\end{array}$ & -- & 1 & 3 \\
\hline
\end{tabular}

The lead may also corrode when exposed to the vapors of acetic acid off-gas. However, as with all atmospheric corrosion mechanism, this is a complex function of the condensate on the lead material. The organic acids are condensed in aqueous surface film, and the lead carbonate compounds on the surface undergo an acid dissolution into soluble lead acetate or lead acetate oxide hydrate. The subsequent migration of this concentrated solution of acetate compounds into the cracks of the corrosion layer towards the metal surface leads to the dissolution of the $\mathrm{PbO}$ under layer, the oxidation of lead, then the peeling of the carbonate layer. [10] This is schematically shown in Figure 3. 
WSRC-TR-2006-00094

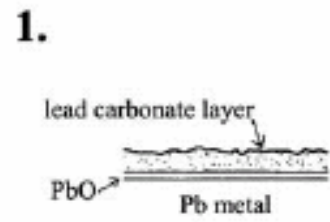

2.

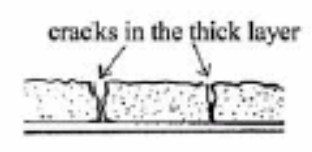

3.

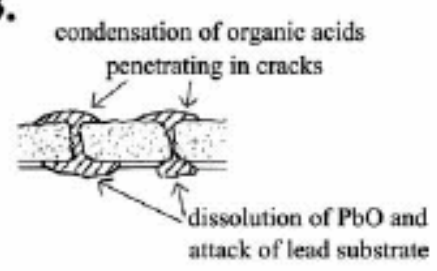

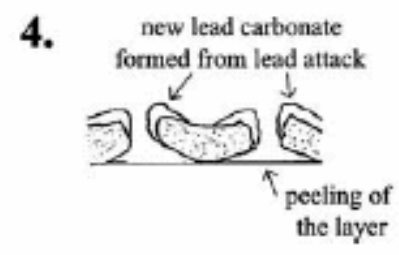

5.

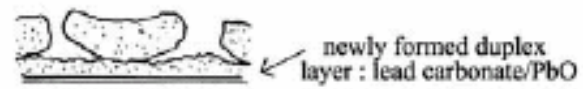

Figure 3: Schematic of Atmospheric Lead Corrosion due to Acetic Acid.[10]

\section{EXPERIMENTAL APPROACH}

The experimental approach focused on the effect of the acetic acid emissions from organic components of the model 9975 package on the corrosion of lead. The testing included analysis of the corrosion of the lead as a function of the aging of the organic materials. The geometry of the package and the location of the corrosion indicate that the Celotex ${ }^{\circledR}$, PVAc wood glue, or the silicone are most probably involved in the corrosion process, and all could be the source of the acetic acid. The corrosion may be atmospheric in nature or in aqueous solution if the annular gap between the lead and the Celotex ${ }^{\circledR}$ assembly allows significant condensation.

\subsection{Experimental Test Matrix}

The experimental matrix was a parametric combination of the following discrete variables: (1) configuration of the organic materials, (2) temperature, (3) humidity, and (4) duration of exposure. The variables are summarized in Table 3.

Table 3: Summary of Discrete Variables in Parametric Test Matrix

\begin{tabular}{|c|c|c|c|}
\hline $\begin{array}{c}\text { Configuration of Organic } \\
\text { Materials }\end{array}$ & Temperature $\left({ }^{\circ} \mathbf{C}\right)$ & Humidity & $\begin{array}{c}\text { Duration of } \\
\text { Exposure (days) }\end{array}$ \\
\hline Celotex & Ambient & Ambient & 30 \\
\hline Glue & 50 & Condensed water & 75 \\
\hline RTV & 75 & & 120 \\
\hline Celotex + Glue & & & \\
\hline Celotex + Glue + RTV & & & \\
\hline
\end{tabular}

Each of the discrete variables for exposure of the coupons was chosen on the basis of their influence on the corrosion of lead. The testing was performed by exposing lead coupons, purchased to the ASTM B749 Standard, to the various organic configurations to determine the effect of each organic component as well as synergistic effects.[11] The temperatures tested covered the expected boundary conditions in the package. The humidities were tested at ambient and with "condensed water" indicating a small amount of standing water thereby creating a $100 \%$ relative humidity environment. The duration of exposure was tested to determine any change in corrosion rate, or confirming the true self-sustaining nature of the corrosion phenomena. Additionally, the coupons exposed to 30 days and analyzed were placed back into exposure to simulate the opening and closing of the packages and potentially replenishing the carbon dioxide supply to further support the corrosion reaction. 


\subsection{1 $\quad$ Celotex $^{\circledR}$}

The Celotex ${ }^{\circledR}$ is cane-fiberboard composed of cellulose $(\leq 96 \%)$, starch $(\leq 10 \%)$, clay $(\leq 2 \%)$, carbon black $(<0.5 \%)$, paraffin wax binder $(\leq 2 \%)$. The Celotex materials can emit acetic acid vapor particularly when exposed to water due to hydrolysis of its cellulose backbone.[12] The extent of the vapor emission can be a function of the initial acetic acid concentration as well as cellulose concentration.[13] The Celotex ${ }^{\circledR}$ materials used for the testing were harvested from a model 9975 package spare parts assembly.

\subsubsection{Polyvinyl Acetate (PVAc)}

The Elmers ${ }^{\circledR}$ E690 wood glue is a water based thermoplastic adhesive commonly used as an emulsion of PVAc polymers in water. The PVAc glue can off-gas during the curing process, or when hydrolyzed in the presence of water. The hydrolysis of the PVAc creates PVOH and acetic acid which can be accelerated by higher temperatures, and is self catalyzed by the acetic acid.[14]

\subsubsection{RTV}

The Dow-Corning 732 is a Silicone-based sealant that is a two-part room temperature vulcanizing material (RTV) which cures via the silicone molecule's silanol ends. When the organic groups polymerize, a volatile species is generally released - the most common being acetic acid.[15] The sealant typically does not continue to off-gas acetic acid when completely cured; however, it can release acetic acid if it degrades. In this case, the silicone may contribute to the acetic acid within the package due to prolonged exposure, once again, due to hydrolysis.

\subsubsection{Water and Carbon Dioxide}

It is important to identify the source of the water vapor and the carbon dioxide in the package. The outer drum is not a pressure or leak tight boundary, but typically does not promote atmospheric exchange with the Celotex ${ }^{\circledR}$ assembly. The Celotex has significant porosity potentially containing humid air providing water as well as the carbon dioxide for the reactions to take place. Measurements of the moisture content of Celotex ${ }^{\circledR}$ in the 9975 package shows typical levels of $12-14 \%$ wood moisture equivalent. This represents equilibrium with an atmospheric humidity level of $65-75 \%$ at $70^{\circ} \mathrm{F}$.[16] The maximum allowable water absorption is $7-15 \%$ depending upon thickness of the wall sheathing materials as outlined by ASTM Standard C208, "Standard Specification for Cellulosic Fiber Insulating Board".

\subsection{Experimental Setup}

Testing for each unique condition was done in a $125-\mathrm{mL}$ clear glass septa bottle as shown in Figure 4 . The coupons were mounted on a stainless steel rack perforated base stud (Figure 5) with the organic assemblies. The assemblies and the coupons were separated using Teflon washers and nuts. Coupons were weighed, measured, and photographed before and after exposures.

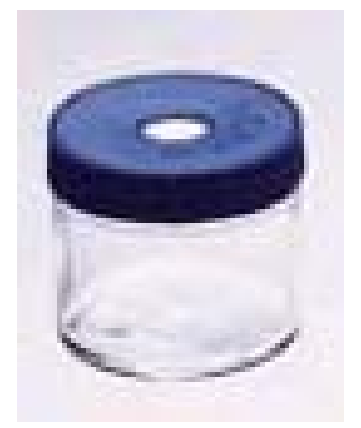

Figure 4: $125 \mathrm{~mL}$ Glass Vial with Septum 
WSRC-TR-2006-00094

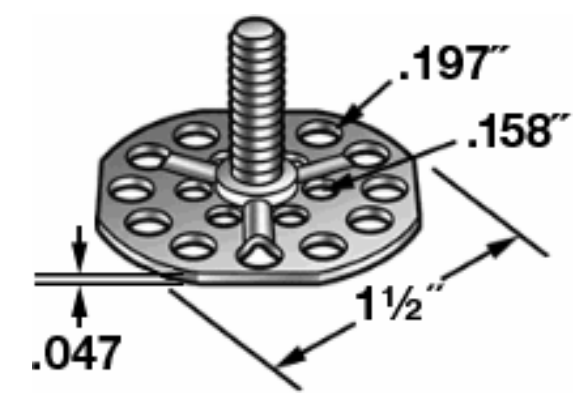

Figure 5: Perforated Base Stud to be Used as Coupon Rack

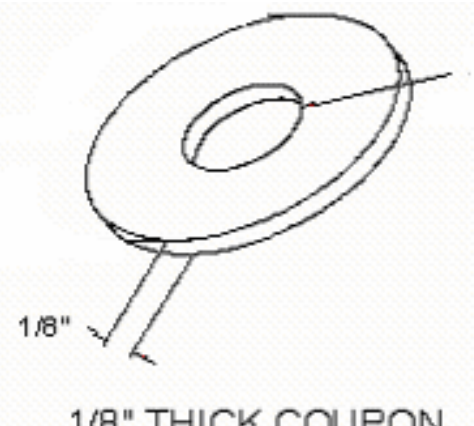

Figure 6: Nominal Lead Sample (OD = 1.5-in., ID - 0.312 in.)

The coupons were analyzed for corrosion after the exposure testing. The coating thickness was measured with a $x-y$ traveling stage microscopy after scraping the edge to reveal the underlying lead coupon with the carbonate coating. This measured coating thickness was used to calculate the corrosion rate.

\section{RESULTS}

The coupons were analyzed after completion of their exposures. The coupons that were exposed for 30 and 75 days were re-exposed and analyzed after 120 day to simulate the opening and closing of the package. Photographs were taken of each side of the coupon. Photographs of each of the coupons with one-time exposures are shown in Appendix A for 30 day exposures and Appendix B for 75 days demarcated by the configuration of organic materials and the temperature. Appendix C contains photographs for all the coupons when they were removed from the 120 days exposures, also demarcated by coupon and temperature. Appendix $\mathrm{C}$ also contains photographs of the 30 and 75-day coupons after re-exposure.

The coupons were weighed and dimensioned. The carbonate thickness was measured when possible by scraping a portion of the edge and using an $x-y$ traveling microscopic stage. The corrosion rate was calculated assuming that the carbonate layer consisted of 50\% cerrusite and 50\% hydrocerrusite. This implies that for every $1 \mathrm{mil}$ of coating thickness, there is 0.425 " lead lost. The corrosion rates are all reported as amount of lead metal lost per unit of time. The rates were calculated using the following formula

\section{Equation 1: Calculation of Lead Corrosion Rate}

$$
\frac{\text { CoatingThickness }}{\text { Duration }}[0.425]=\frac{\text { LeadLost }(\text { mils })}{\text { Year }}
$$

The corrosion rate was calculated for the coupons that were exposed for the complete duration of exposures and also for the coupons that were re-exposed after interim analysis. The corrosion rates for the coupons exposed to the cells with condensed water were calculated. The calculated corrosion rates are reported in Figure $7-15$ for each of the temperatures, durations, and organic configurations tested. Rates are also reported for the coupons that were reexposed after interim analysis. 
Visual observations were made on coupons exposed to cells without condensed water, since these coupons did not exhibit measurable corrosion. The visual observations made on coupons which exhibited only minor corrosion when exposed to the cells with ambient humidity are discussed following the sections on corrosion rates.

\subsection{Corrosion Rate Analysis for the Coupons Exposed in Condensed Water Cells}

The corrosion rates for the lead coupons exposed in the condensed water cells for the complete duration of exposure are shown in Figure 7 - Figure 9, for room temperature, $50^{\circ} \mathrm{C}$, and $75^{\circ} \mathrm{C}$ respectively.

The PVAc glue induced corrosion of the lead metal, but did not sustain a linear corrosion rate as would be expected by the self-sustaining reaction. This is hypothesized to be either due to the variability of the degree of initial curing of the PVAc glue when placed into test or the consumption of available reactants during the exposure. The glue sample placed into the 30/75-day test cells was observed to be poorly cured relative to the glue samples placed in the 120-day cell. Since the cells were not opened during the 120-day exposure period, the available $\mathrm{CO}_{2}$ or $\mathrm{H}_{2} \mathrm{O}$ may have been consumed sufficiently to decelerate the corrosion of the lead metal.

Higher temperatures led to higher corrosion rates as well as corrosion of lead from exposure to only Celotex ${ }^{\circ}$, whereas at room temperature, there was no measurable corrosion in this configuration. The corrosion rate of lead when exposed to the PVAc glue did not sustain a linear rate even at the higher temperatures.

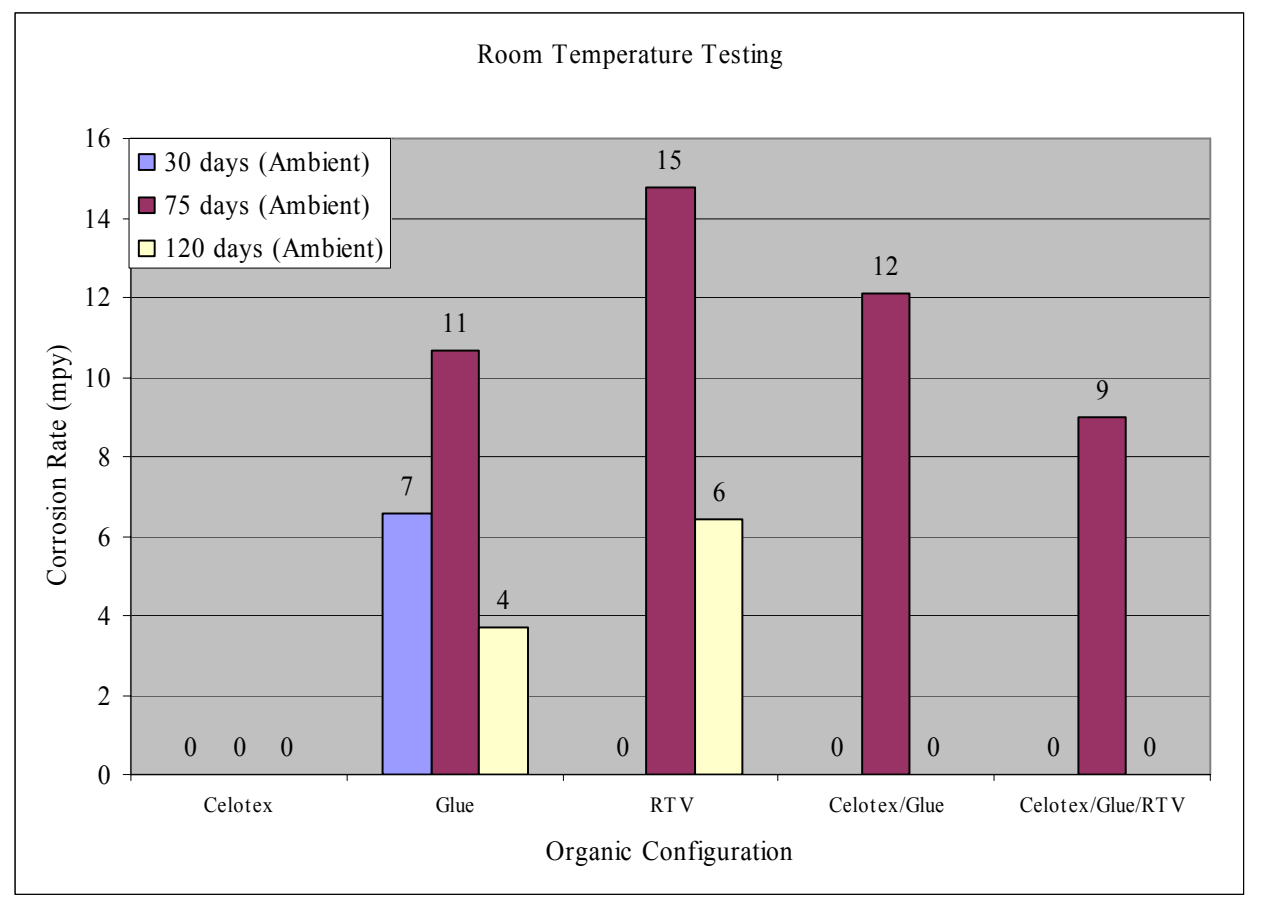

Figure 7: Corrosion Rates for Lead Coupons Exposed to Condensed Water Cells at Room Temperature for Complete Duration of Exposure

The highest corrosion rate at both of the higher temperatures tested was the Celotex ${ }^{\circ}$ Glue/RTV configuration. Judging from the corrosion rate of lead when exposed only to RTV, it is hypothesized that this corrosion rate may have been induced primarily by the RTV. 


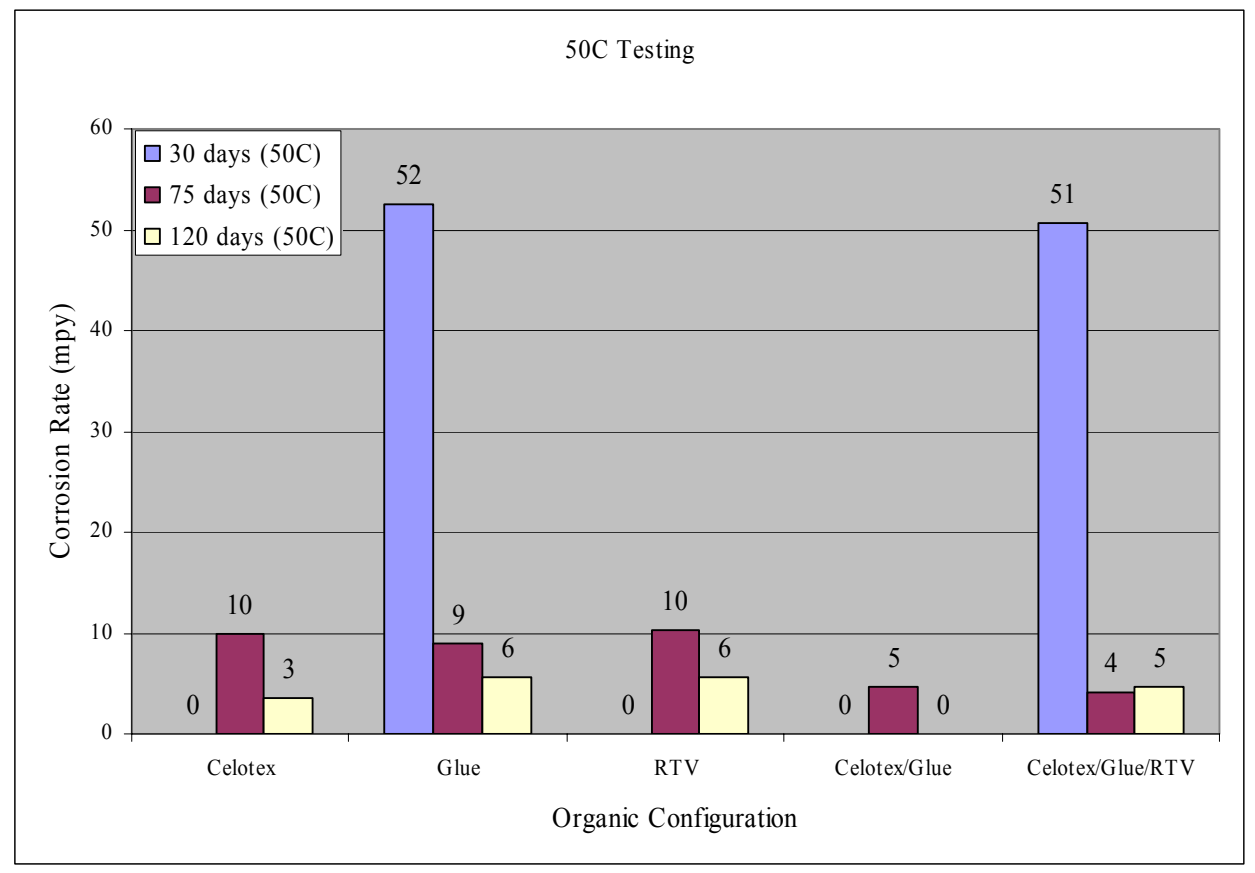

Figure 8: Corrosion Rates for Lead Coupons to Condensed Water Cells at $50^{\circ} \mathrm{C}$ for Complete Duration of Exposure

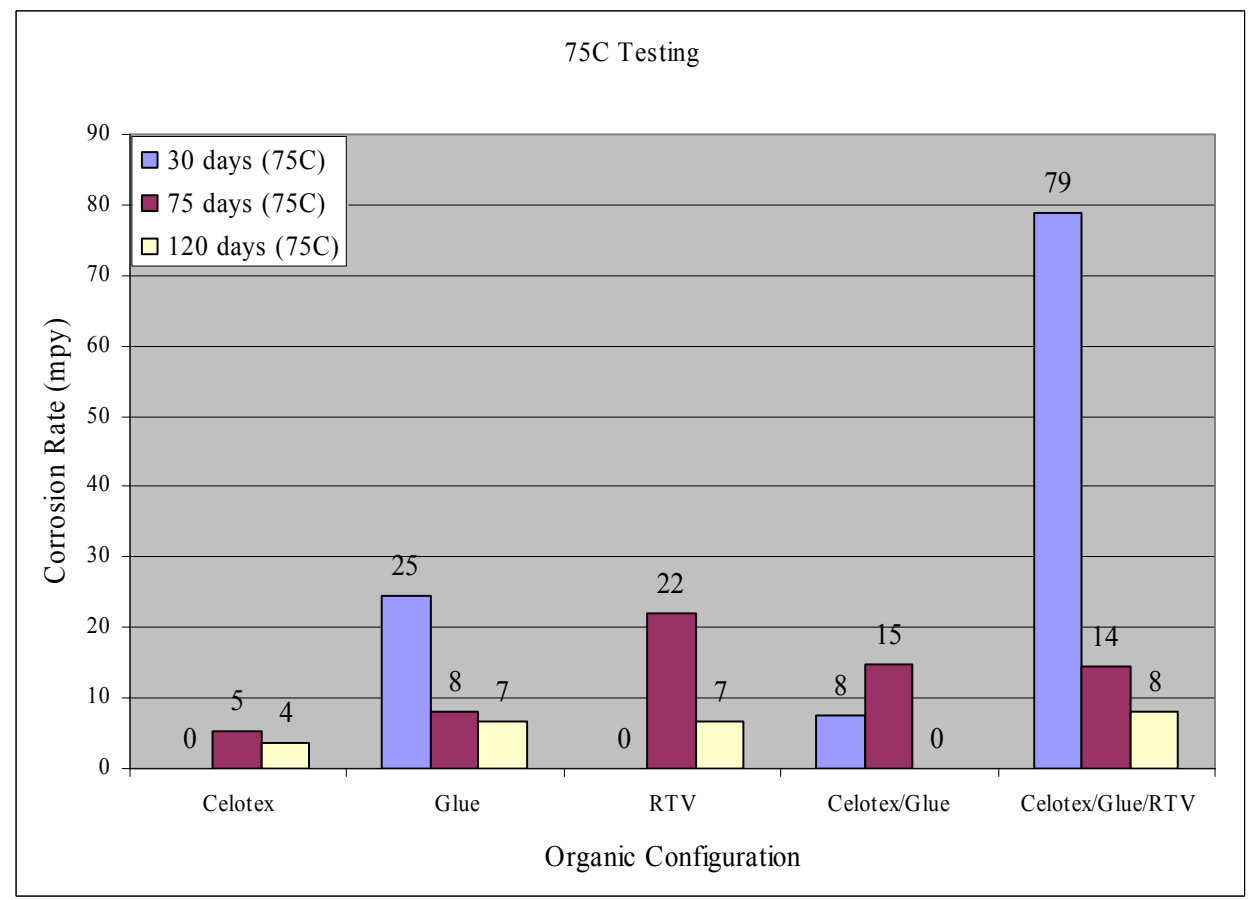

Figure 9: Corrosion Rates for Lead Coupons Exposed to Condensed Water Cells at $75^{\circ} \mathrm{C}$ for Complete Duration of Exposure

The corrosion rate data for the lead coupons exposed to the condensed water cells for the re-exposed coupons are shown in Figure 10 - Figure 12, for exposure at room temperature, $50^{\circ} \mathrm{C}$, and $75^{\circ} \mathrm{C}$ respectively. The 120 -day 
coupons are included for comparison purposes. In contrast to the initial 30-day exposures, re-exposure and replenishment of reactionary species at room temperature induced corrosion in the Celotex ${ }^{\odot}$ sample for the 30 -day test.

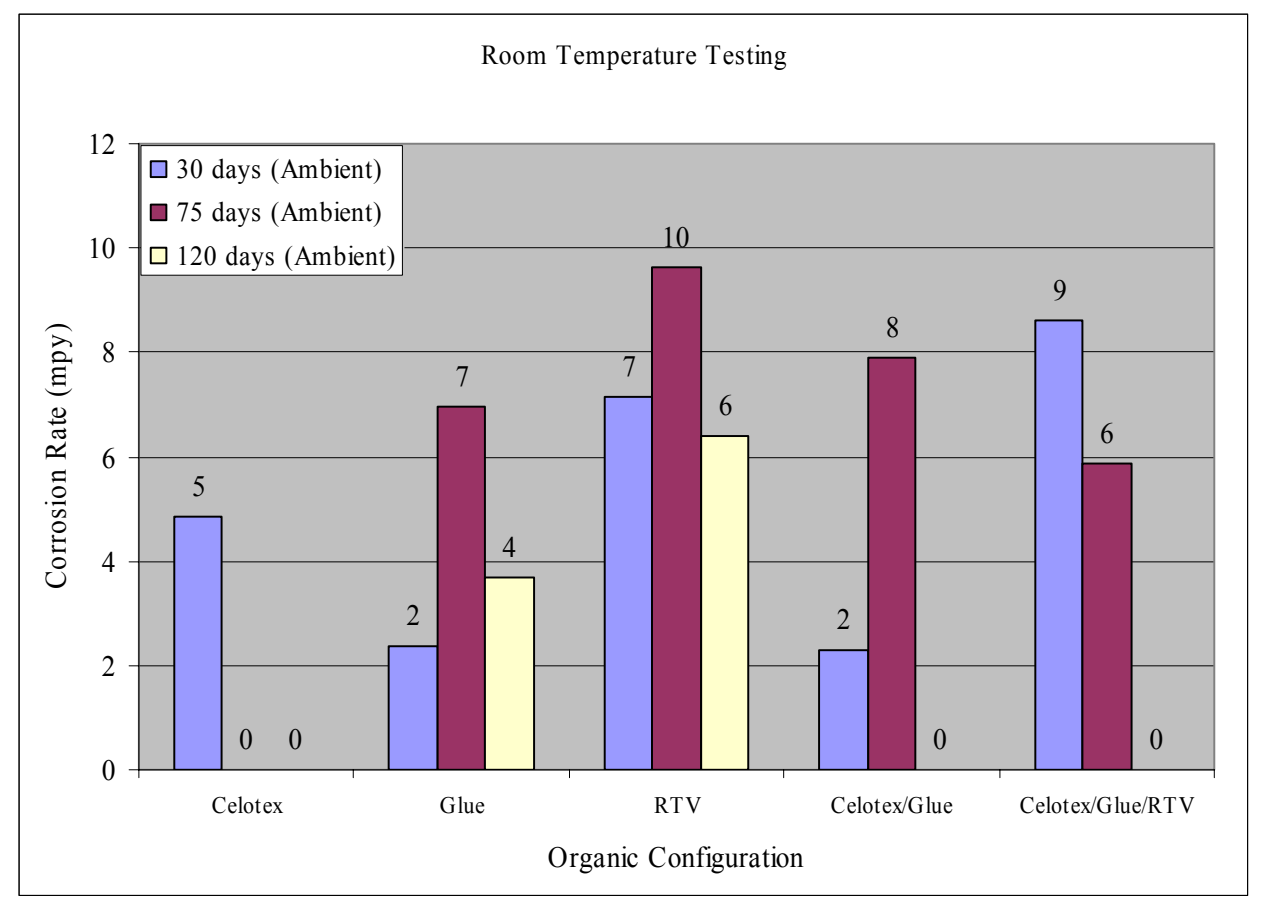

Figure 10: Corrosion Rates for Lead Coupons Exposed to Condensed Water Cells at Room Temperature for Re-Exposed Coupons and 120-Day Coupons

Corrosion was seen on all re-exposed coupons at higher temperatures, indicating that replenishment of reactionary species, i.e. $\mathrm{CO}_{2}$ and $\mathrm{H}_{2} \mathrm{O}$ may be a key factor in inducing corrosion of lead in the long-term. This is further corroborated since the re-exposed coupons exhibited higher corrosion rates than the 120-day coupons that were never removed out of test for all organic configurations. 


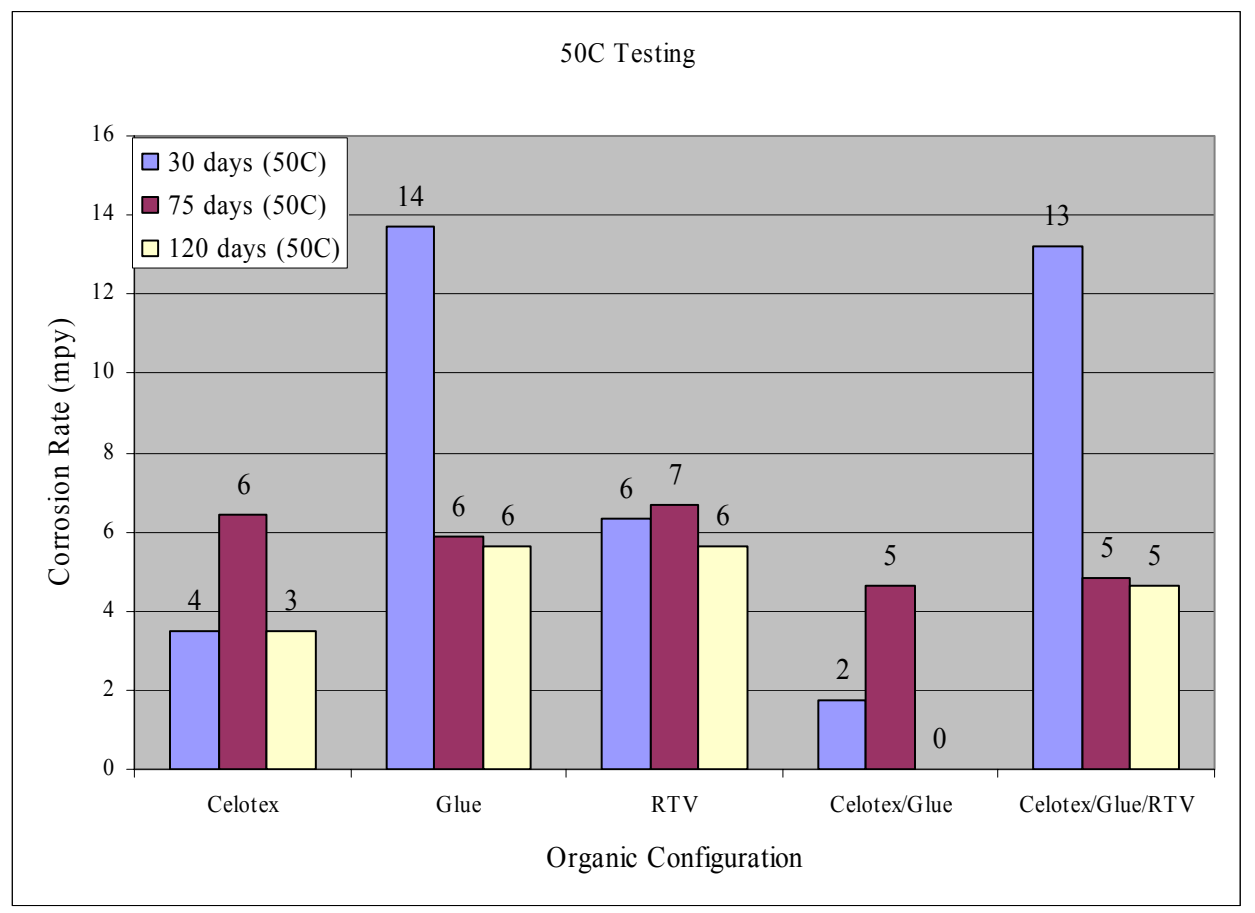

Figure 11: Corrosion Rates for Lead Coupons Exposed to Condensed Water Cells at $50^{\circ} \mathrm{C}$ for Re-Exposed Coupons and 120-Day Coupons

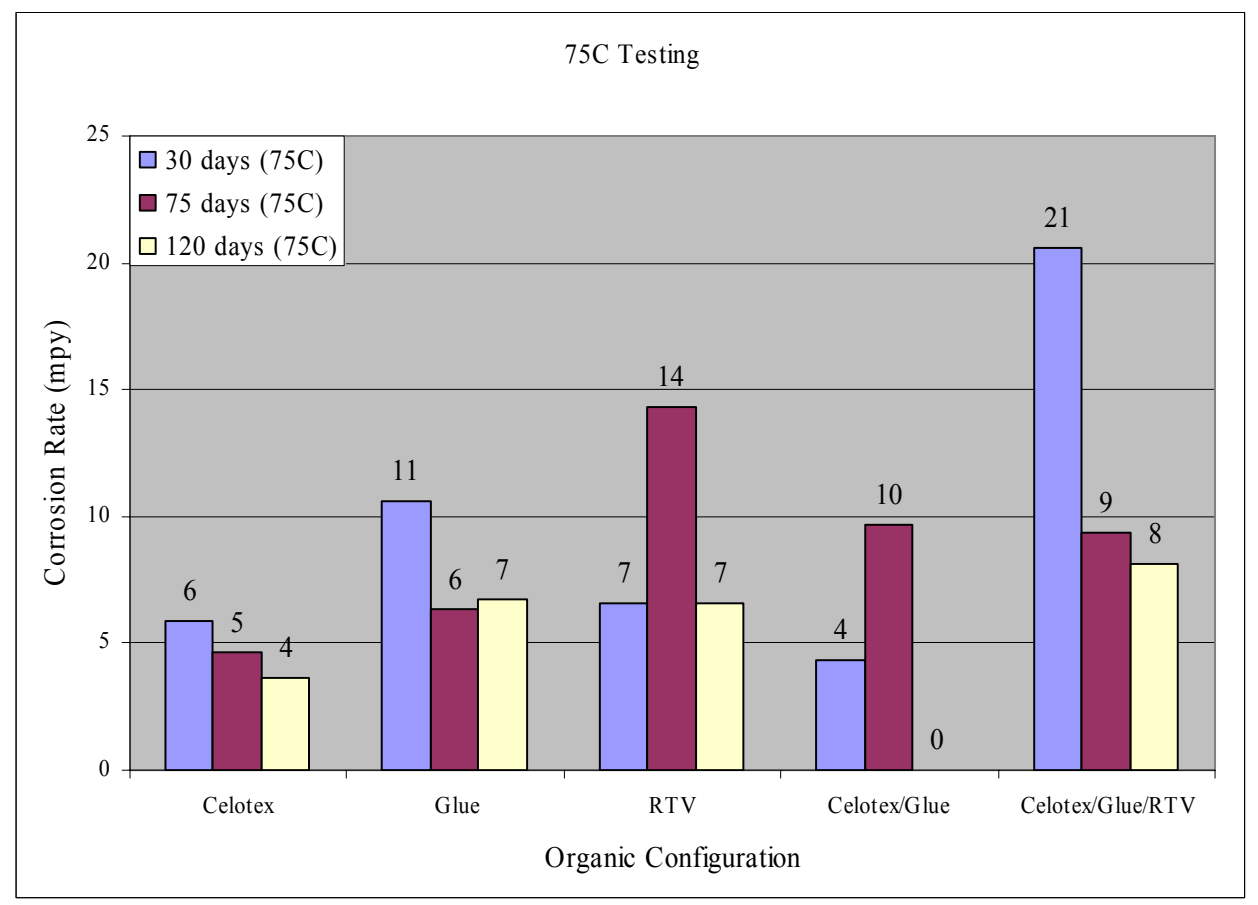

Figure 12: Corrosion Rates for Lead Coupons Exposed to Condensed Water Cells at $75^{\circ} \mathrm{C}$ for Re-Exposed Coupons and 120-Day Coupons 


\subsection{Corrosion Rate Analysis for the Coupons Exposed in Ambient Humidity Cells}

The corrosion rates for the ambient humidity cells were measured and calculated when possible. The lead coupons that were initially exposed for the $30 / 75$ day cycles, then re-exposed were the only coupons that exhibited any measurable coupons. The corrosion rate data for the lead coupons exposed to the condensed water cells for the reexposed coupons are shown in Figure 10 - Figure 12, for exposure at room temperature, $50^{\circ} \mathrm{C}$, and $75^{\circ} \mathrm{C}$ respectively. Measurable corrosion occurred on lead coupons exposed to the glue samples in both the 30-day reexposed coupon and the 120-day coupon.

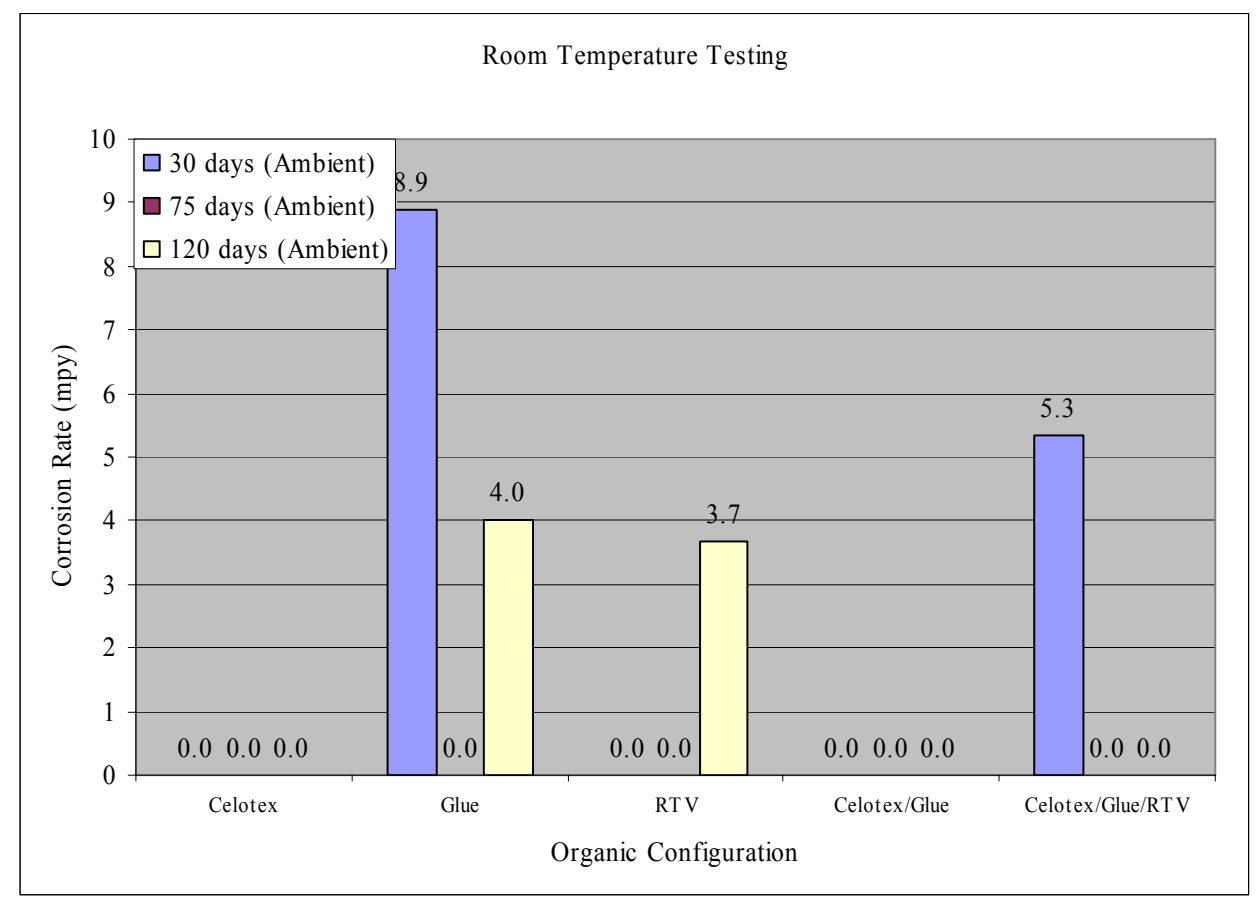

\section{Figure 13: Corrosion Rates for Lead Coupons Exposed to Ambient Humidity Cells at Room Temperature for Re-Exposed Coupons and 120-Day Coupons}

Exposure of the coupons at higher temperatures led to corrosion of lead coupons exposed to more configurations that exposure at room temperature. In addition, the higher temperatures led to higher corrosion rate. Measurable corrosion was on all coupons exposed to the RTV. However, these coupons exhibited much lower (approximately $1 / 2$ ) corrosion rates than the coupons exposed to similar organic configurations with condensed water as described in the previous section.

The initial integrity of the organic assembly is suspected to play a large role in the corrosion response. The initial integrity of the PVAc glue and the RTV material is dependent upon the degree of curing. Both the PVAc and RTV off-gas acetic acid as the polymerize (i.e. cure). In addition, the degree of curing controls the ability of each of these materials to resist hydrolysis and the consequent release of acetic acid. 


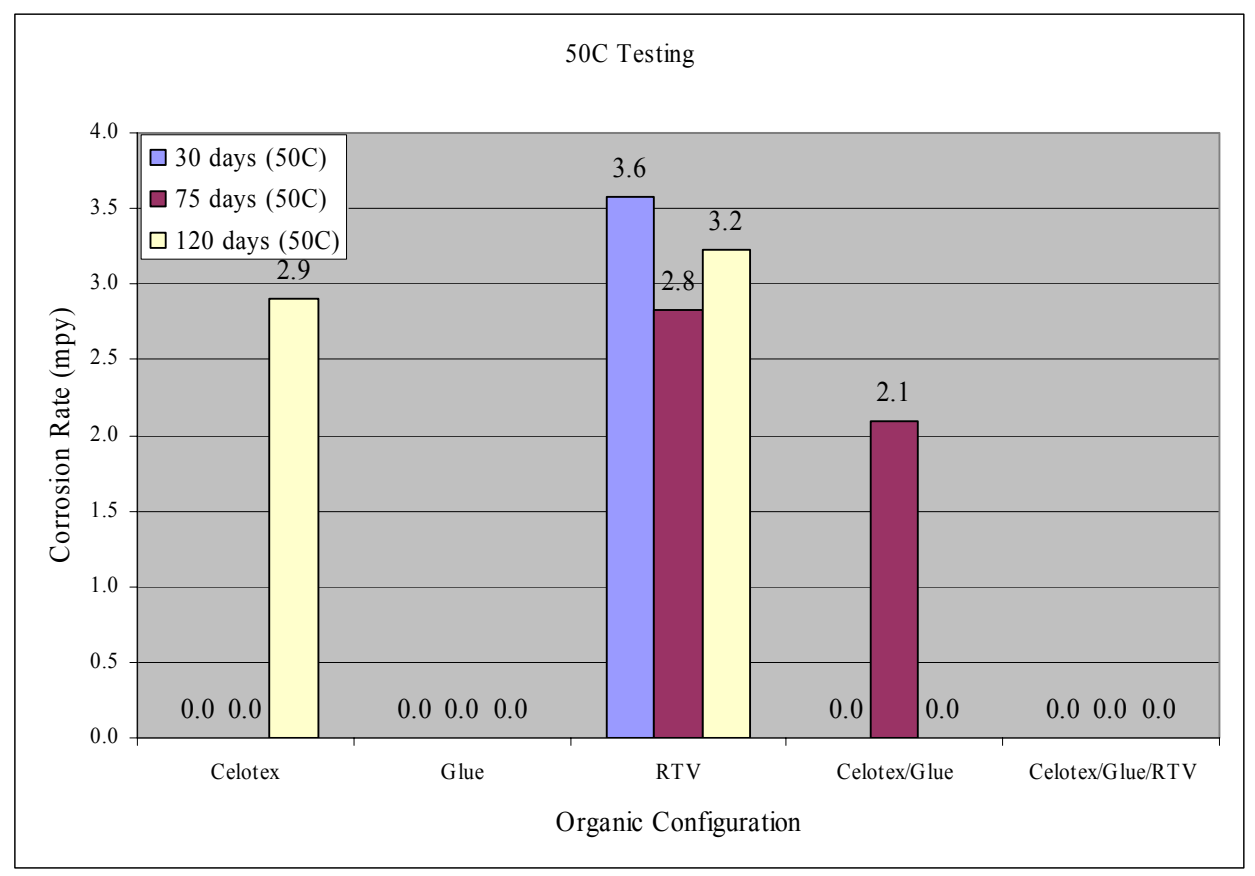

Figure 14: Corrosion Rates for Lead Coupons Exposed to Condensed Water Cells at $50^{\circ} \mathrm{C}$ for Re-Exposed Coupons and 120-Day Coupons

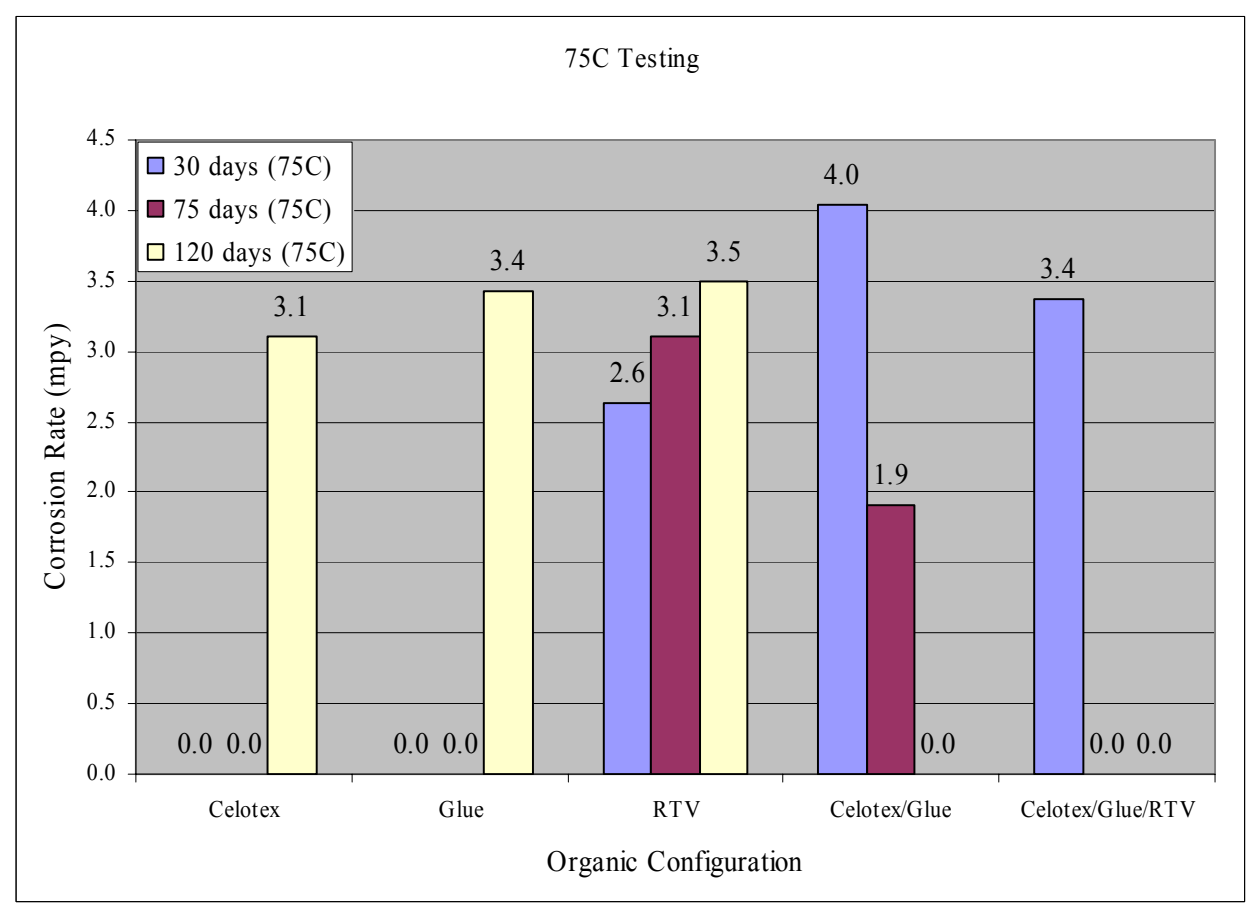

Figure 15: Corrosion Rates for Lead Coupons Exposed to Condensed Water Cells at $75^{\circ} \mathrm{C}$ for Re-Exposed Coupons and 120-Day Coupons 


\section{DISCUSSION}

The experimental test matrix was developed to determine the effect of organic configuration, temperature, humidity and the effect of durations of exposure on the corrosion of lead in the 9975 package. The corrosion rate data can be used to infer the effect of each of these discrete variables on the lead corrosion response.

The RTV sealant was the most corrosive organic species in the testing. Silicone sealants are based on mixtures of fillers (e.g., silica), silicone polymers, cross linking components, and catalysts. The polymer has a siloxane backbone, i.e., Si-O-Si, with alkyl and alkoxy or acetoxy pendant groups. The latter are readily hydrolyzed to silanol groups $(\mathrm{SiOH})$ which form larger chains by condensation and loss of alcohol or acetic acid. When the organic groups polymerize, a volatile species is generally released - the most common being acetic acid.[17] The RTV $n$ the model 9975 package may contribute to the acetic acid within the package. However, the geometry of the package is such that the RTV is not in intimate contact with the lead, and the other components are the likely major contributors to the corrosion of the lead.

The PVAc glue was the next most aggressive species in the testing. It is formed by polymerization of vinyl monomers in water and then cures by evaporation of water. PVAc creates strong bonds in wood but is not moisture or heat resistant. The addition of cross-linking agents to the PVAc can increase the moisture and heat resistance but lowers the tack quality of the adhesive.[18] The PVAc used for the 9975 assembly is not cross-linked and thus softens as its temperature is raised above room temperature, and it is less resistant to moisture and humidity than thermosetting resins. As a result, the use of PVAc is not recommended in high temperature or high humidity environments.[18] Another key facet of the PVAc is the availability of free hydroxyl groups. The free hydroxyl groups are available since PVAc is polymerized with minor amounts of vinyl alcohol, and also can be formed by hydrolysis of the acetate groups. Vinyl acetate, the monomer for PVAc polymerization, is also produced by catalytic oxidative condensation of acetic acid and ethylene.[19] In fact, PVAc itself is a primary intermediate for the production of vinyl alcohol. The hydrolysis of the PVAc creates PVOH and acetic acid, per the following reaction. This reaction can be accelerated by higher temperatures, and is self catalyzed by the acetic acid.[20]

$$
-\mathrm{CH}_{2}-\mathrm{CH}-\mathrm{OCOCH}{ }_{3}+\mathrm{H}_{2} \mathrm{O} \rightarrow-\mathrm{CH}_{2}-\mathrm{CH}-\mathrm{OH}+\mathrm{CH}_{3} \mathrm{COOH} \text { (Acetic Acid) }
$$

The PVAc glue is suspected to the primary source of acetic acid in the model 9975 package. The humidity and the temperatures within the package are sufficient to degrade the PVAc glue, particularly if incompletely cured during the manufacturing process. The PVAc glue is nearly in intimate contact with the lead shielding in the package, with sufficient vapor space in between to allow for build-up of acetic acid emissions. In addition, the $\mathrm{CO}_{2}$ and $\mathrm{H}_{2} \mathrm{O}$ within this vapor space are sufficient to support the corrosion reactions as well as to continue to degrade the PVAc.

The temperature also had an effect on the corrosion response of the lead. The coupons exhibited faster corrosion at higher temperatures than at room temperatures. There was a pronounced effect of condensed water as the coupons exposed in the cells with condensed water exhibited much higher corrosion rates. This can be specifically compared for the RTV configurations, where the corrosion rates doubled as a function of moisture and temperature.

The corrosion of the lead was also determined to be a function of the duration of exposure. The corrosion rates did not maintain a linear rate as expected per the corrosion mechanism as expected. This may have been due to the depletion of reactants for the longer exposures or due to the incongruity of the initial condition of the organic samples. However, the coupons that were re-exposed after opening and closing in specific situations exhibited higher corrosion than the coupons that had complete 120-day exposures. This was particularly seen in the ambient humidity conditions, where the moisture content would have been replenished when opened and closed.

\section{CONCLUSIONS AND RECOMMENDATIONS}

The data can be used to draw several conclusions on the corrosion of the lead shielding in the model 9975 package. The testing confirmed that the organics of the model 9975 package cause corrosion of the lead shielding through acetic acid emissions. The RTV sealant was determined to the most aggressive in the experiments, followed by the PVAc glue. In the 9975 package, the PVAc glue was determined to be the most aggressive due to it's proximity in the design. The curing process of the PVAc glue is a key parameter for the lead corrosion. Poorly cured PVAc glue during package construction will lead to greater acetic-acid emission as it continues to cure in the package or during degradation in the warm, moist environment of the package 
The condition considered most representative of the package conditions is that of the coupon exposed to the Celotex $\%$ glue organic exposed in the ambient humidity conditions. The Celotex $\%$ glue laminate in the package is nearly in intimate contact with the lead shielding as in the test setup. In addition the package will have high relative humidity conditions, but is not expected to have condensed water due to the heat. The water can be in the vapor space, or physisorbed on the surfaces with the Celotex ${ }^{\circledR}$. The corrosion rate of lead when exposed to these conditions was $2 \mathrm{mpy}$ and is recommended as a bounding conditions for package performance calculations. This is considered a bounding condition due to the relatively aggressive nature of the test setup in comparison with the model 9975 package. In contrast to the more benign conditions in the model 9975 package, the experiments were done in small volume containers with a relatively large lead metal surface area exposed. In addition, the organic materials was also exposed within the small volume container and was subject to degradation over a much larger surface area exposed and consequently would lead to greater acetic acid emission. Lastly, the extremely aggressive PVAc glue in the experimental setup were large in volume relative to the test container, and also not completely cured. It is expected that the $2 \mathrm{mpy}$ rate will diminish over time if the primary source of acetic acid is the continued curing of a poorly cured glue. Additionally, it is expected that the opening and closing of the package will allow the acetic acid vapor to escape thereby temporarily stalling the corrosion process, while replenishing the carbon dioxide and moisture required to support the reaction.

\section{ACKNOWLEDGEMENTS}

The author gratefully acknowledges for Karen R. Hicks for performing the experiments and technician support throughout the project. The author also gratefully acknowledges W.L. Daugherty, T.E. Skidmore, K.J. Imrich, and A. Jurgenson for the technical support and analyses. 


\section{REFERENCES}

[1] From K. H. Subramanian to J. L. Murphy, "Test Plan for Corrosion Testing of Lead Metal Exposed to Organics of Model 9975 Package,” SRNL-MTS-2005-50016, July 14, 2005.

[2] L.S. Yerger, “9975 SN 2173 Degraded Lead Shield,” 2004-NCR-29-0040, October 2004.

[3] K.H. Subramanian "Mechanism for Corrosion of Lead Shielding in Model 9975 Package (U)," WSRC-TR2005-00193," June 2005.

[4] M.E. Wangler, Headquarters Certifying Official, Package Approval and Safety Program, Department of Energy, Safety Evaluation Report, Docket 00-26-9975, December 2001.

[5] Material Safety Data Sheet 00040-85F, "Premium Fiberboard Insulation Sheathing, Manufactured Home USB, Coated 1 \& 6 Sided", Knight-Celotex Fiberboard, April 19, 2002.

[6] F.E. Goodwin, "Lead and Lead Alloys," Uhlig's Corrosion Handbook, $2^{\text {nd }}$ Edition, Edited by R. Winston Revie, John Wiley \& Sons, Inc, 2000.

[7] S.M. Blackshaw and V.D. Daniels, "Testing of Materials for Use in Storage and Display in Museums," The Conservator 3:18 (1979).

[8] R. Edwards, W. Bordass, D. Farrell, "Determination of Acetic and Formic Acid in Lead Corrosion Products by Ion-Exchange Chromatography,” Analyst 122: 1517-1520 (1997).

[9] Handbook of Chemistry and Physics, $51^{\text {st }}$ Edition, CRC Press, 1970-1971, pp. B-103.

[10] E.Rocca, C. Rapin, F. Mirambet, "Inhibition Treatment of the Corrosion of Lead Artifacts in Atmospheric Conditioned and by Acetic Acid Vapor: Use of Sodium Decanoate," Corrosion Science 46:653-665 (2004).

[11] ASTM B749-03, "Standard Specification for Lead and Lead Alloy Strip, Sheet, and Plate Products."

[12] P.C. Arni, G.C. Cochrane, J.D. Gray, "The Emission of Corrosion Vapours by Wood:I. Survey of the AcidRelease Properties of Certain Freshly Felled Hardwoods and Softwoods," Journal of Applied Chemistry, 15:305-313, 1965.

[13] P.C. Arni, G.C. Cochrane, J.D. Gray, "The Emission of Corrosion Vapours by Wood:II. The Analysis of the Vapours Emitted by Certain Freshly Felled Hardwoods and Softwoods by Gas Chromatography and Spectrophotometry," Journal of Applied Chemistry, 15:463-468, 1965.

[14] O. L. Wheeler, S. L. Ernst, R. N. Crozier, "Molecular Weight Degradation of Polyvinyl Acetate on Hydrolysis," Journal of Polymer Science, 8 (4): 409-423, March 2003.

[15] N. Singh, B.F. Johnson, J. Cella, and J. Rich, "Tailoring Silicone Fuel Tank Sealants for High Speed Civil Transport Applications," 96CRD091, GE Corporate Research Center, Technical Information Series, July 1996.

[16] W. T. Simpson, "Equilibrium Moisture Content of Wood in Outdoor Locations in the United States and Worldwide," FPL-RN-0268, USDOA - Forestry Service,

[17] N. Singh, B.F. Johnson, J. Cella, and J. Rich, "Tailoring Silicone Fuel Tank Sealants for High Speed Civil Transport Applications," 96CRD091, GE Corporate Research Center, Technical Information Series, July 1996.

[18] E.M. Petrie, Handbook of Adhesives and Sealants, McGraw-Hill, 2000.

[19] Seymour and Carraher, Polymer Chemistry, $4^{\text {th }}$ Edition, 2000. 
[20] O. L. Wheeler, S. L. Ernst, R. N. Crozier, "Molecular Weight Degradation of Polyvinyl Acetate on Hydrolysis," Journal of Polymer Science, 8 (4): 409-423, March 2003. 
APPENDIX A: COUPONS AFTER 30 DAY EXPOSURE.

\section{Day Coupons: Room Temperature}

\section{$\underline{\text { Celotex }}$}

\#1 (with water)

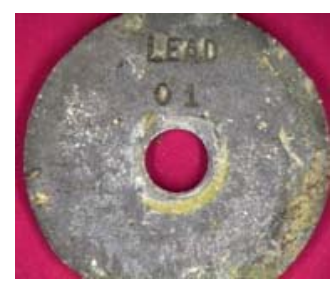

Glue

\#7 (with water)

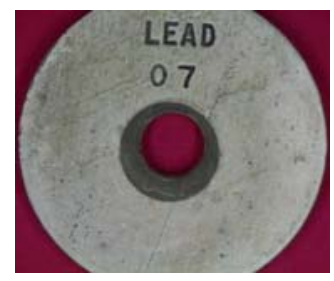

$\underline{\text { RTV }}$

\#13 (with water)

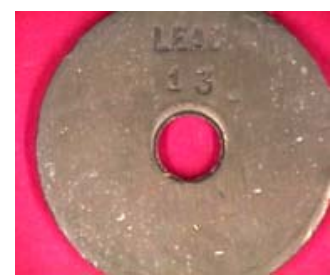

$\underline{\text { Celotex + Glue }}$

\#19 (with water)

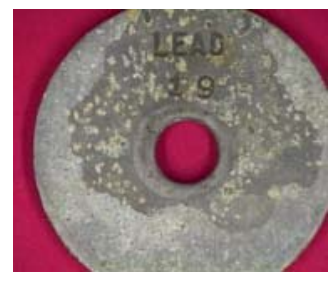

\#1 (with water)

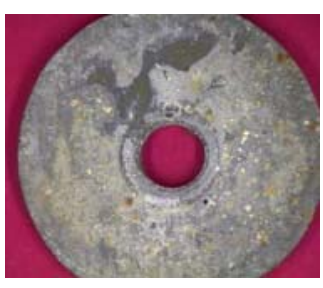

\#7 (with water)

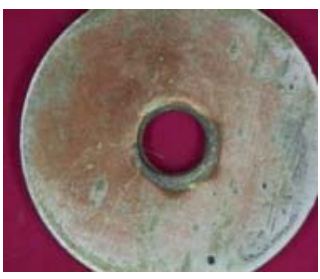

\#13 (with water)

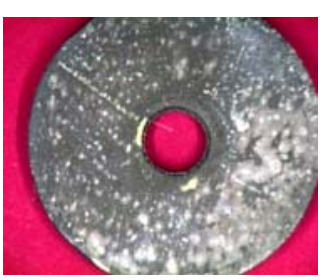

\#19 (with water)

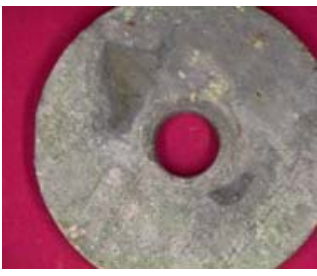

\#2 (w/o water)

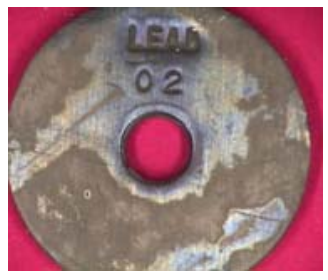

\#8 (w/o water)

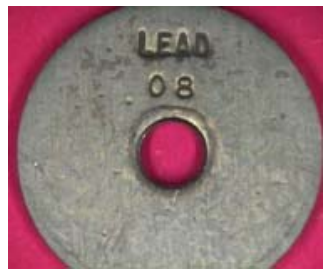

\#14 (w/o water)

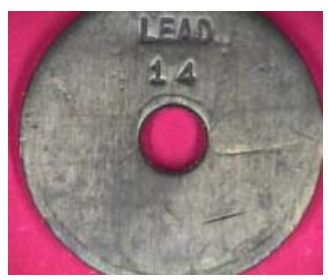

\#20 (w/o water)

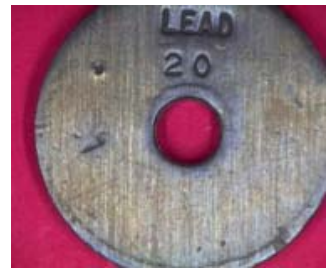

\#2 (w/o water)

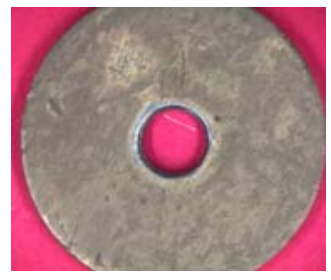

\#8 (w/o water)

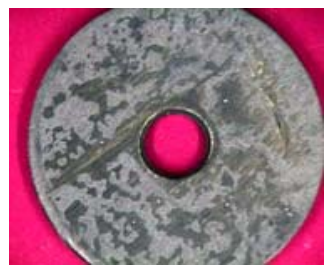

\#14 (w/o water)

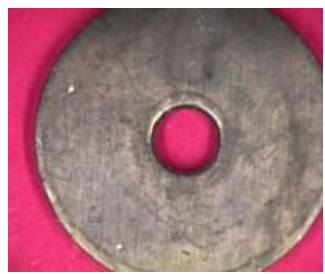

\#20 (w/o water)

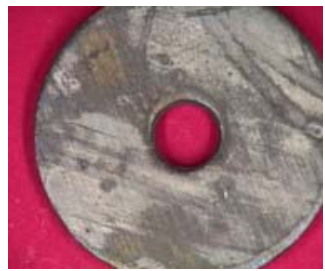




\section{$\underline{\text { Celotex + Glue + RTV }}$}

\#25 (with water)

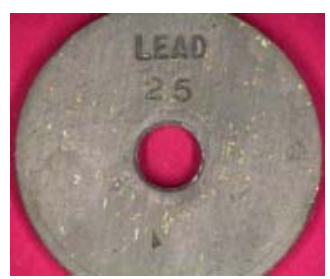

30 Day Coupons: $50^{\circ} \mathrm{C}$

\section{$\underline{\text { Celotex }}$}

\#3 (with water)

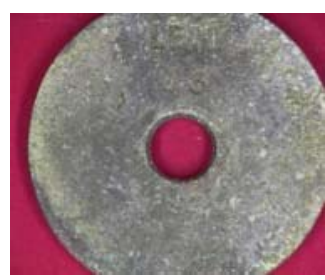

Glue

\#9 (with water)

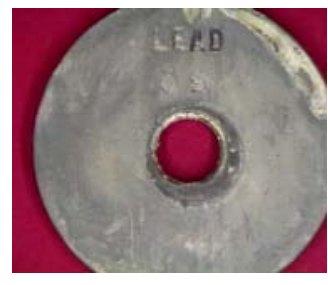

$\underline{\text { RTV }}$

\#15 (with water)

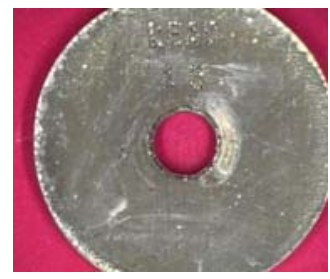

\#25 (with water)

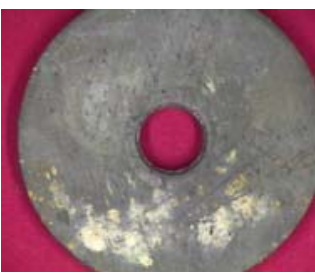

\#3 (with water)

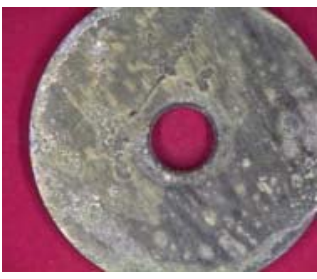

\#9 (with water)

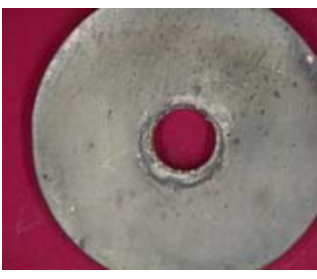

\#15 (with water)

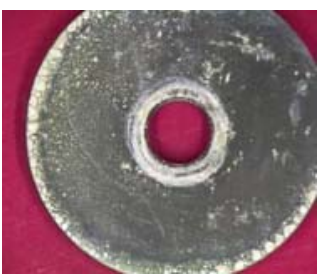

\#26 (w/o water)

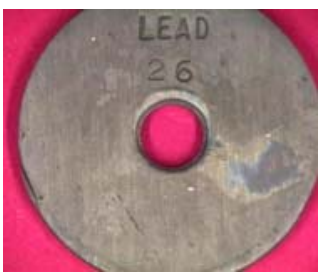

\#4 (w/o water)

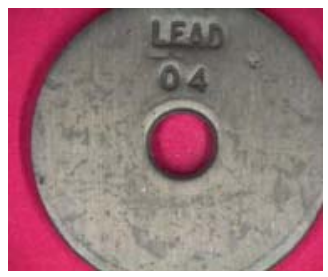

\#10 (w/o water)

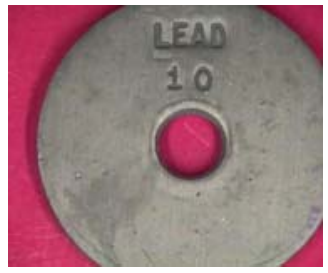

\#16 (w/o water)

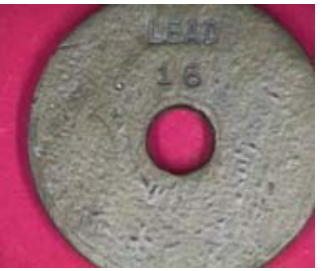

\#26 (w/o water)

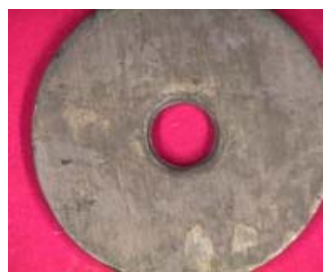

\#4 (w/o water)

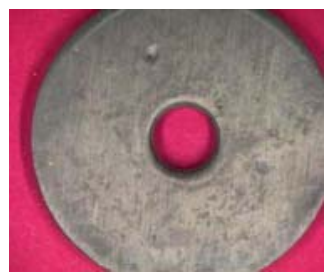

\#10 (w/o water)

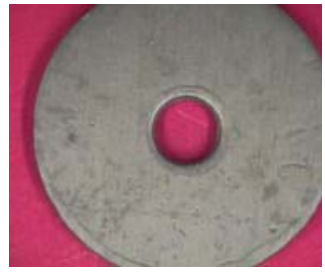

\#16 (w/o water)

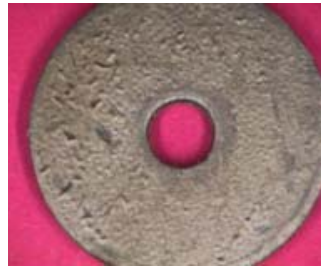




\section{Celotex + Glue}

\#21 (with water)

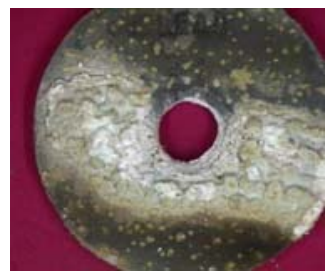

$\underline{\text { Celotex + Glue + RTV }}$

\#27 (with water)

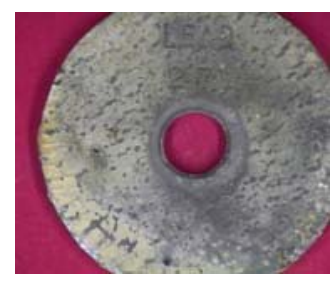

30 Day Coupons: $75^{\circ} \mathrm{C}$

Celotex

\#5 (with water)

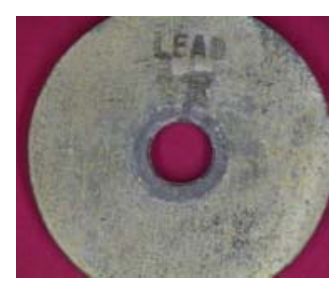

Glue

\#11 (with water)

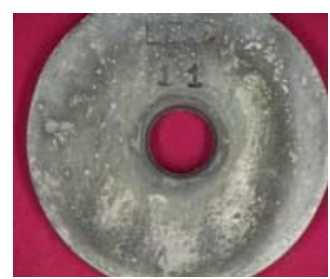

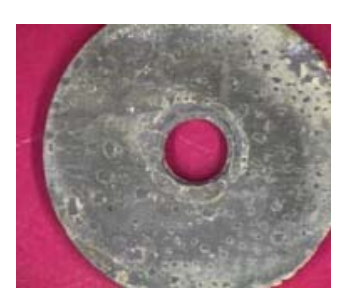

\#21 (with water)

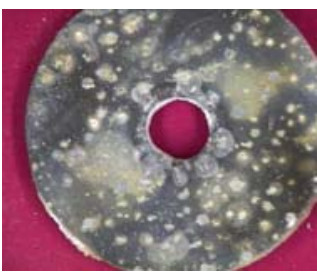

\#27 (with water)

\#5 (with water)

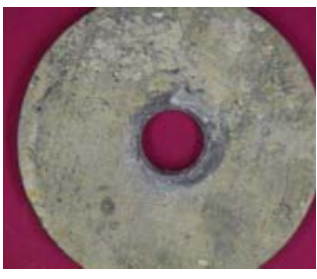

\#11 (with water)

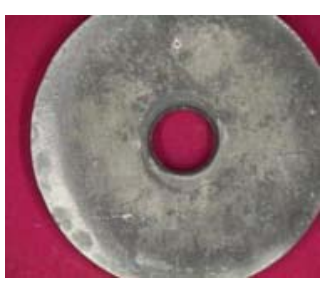

\#22 (w/o water)

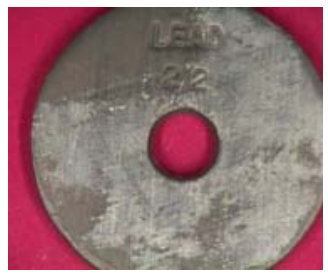

\#28 (w/o water)

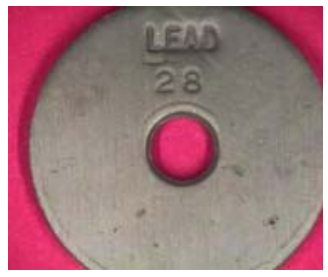

\#6 (w/o water)

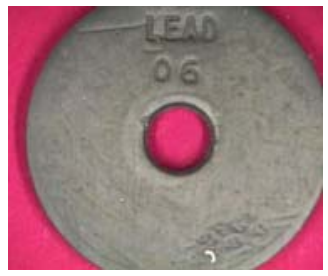

\#12 (w/o water)

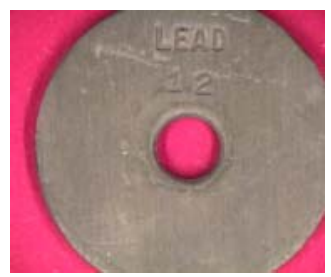

\#22 (w/o water)

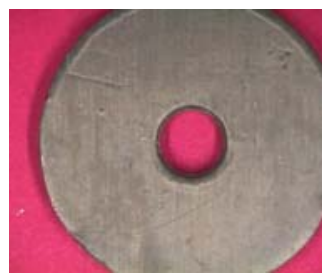

\#28 (w/o water)

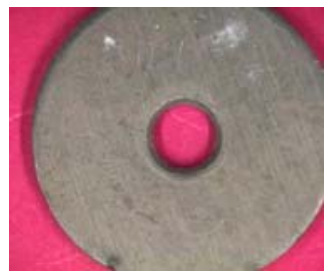

\#6 (w/o water)

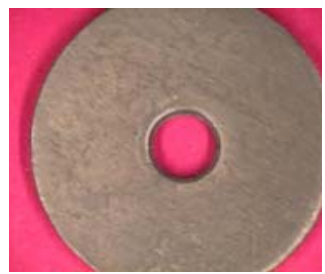

\#12 (w/o water)

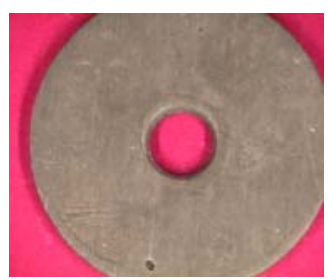




\section{$\underline{\text { RTV }}$}

\#17 (with water)

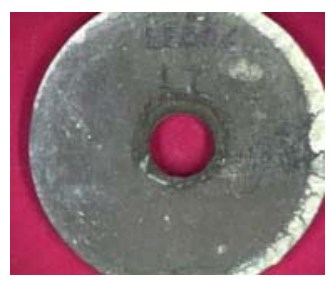

$\underline{\text { Celotex }+ \text { Glue }}$

\#23 (with water)

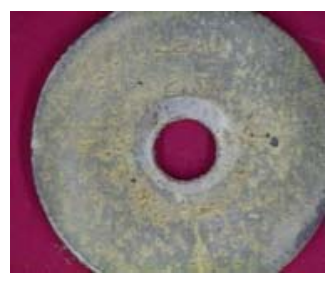

$\underline{\text { Celotex + Glue + RTV }}$

\#29 (with water)

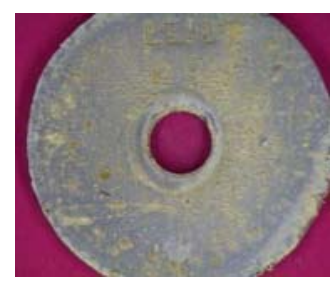

\#17 (with water)

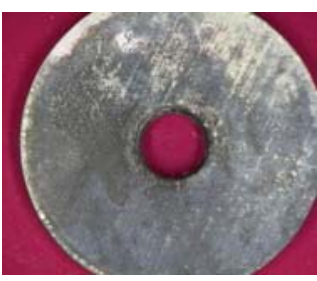

\#23 (with water)

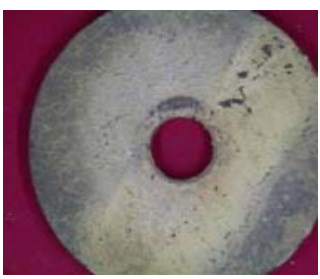

\#29 (with water)

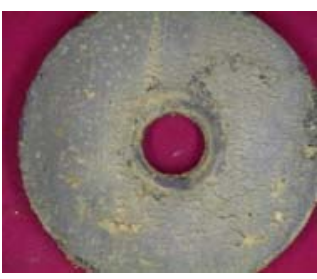

\#18 (w/o water)

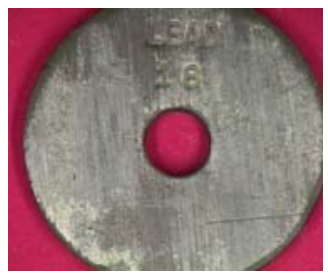

\#24 (w/o water)

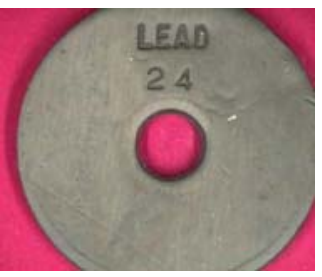

\#30 (w/o water)

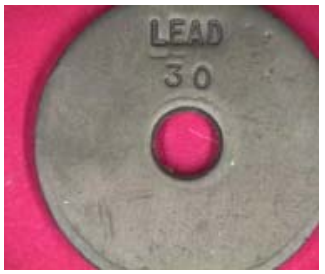

\#18 (w/o water)

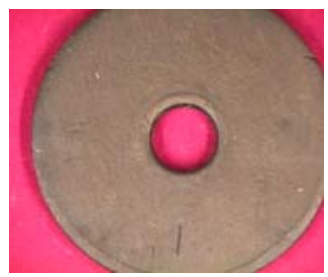

\#24 (w/o water)

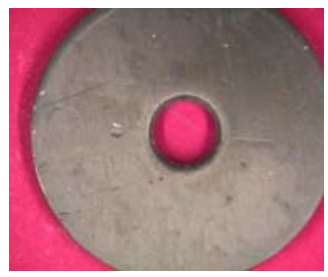

\#30 (w/o water)

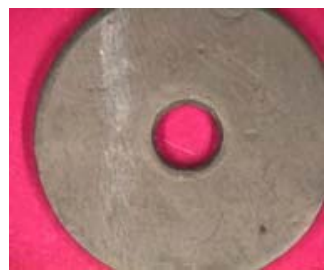


APPENDIX B: COUPONS AFTER EXPOSURE AFTER 75 DAY EXPOSURE.

75 Day Coupons: Room Temperature

$\underline{\text { Celotex }}$

\#31 (with water)

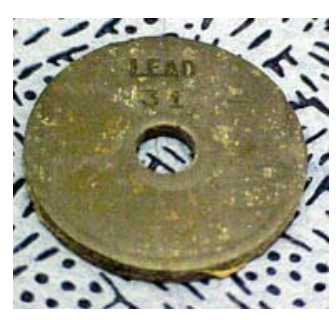

Glue

\#37 (with water)

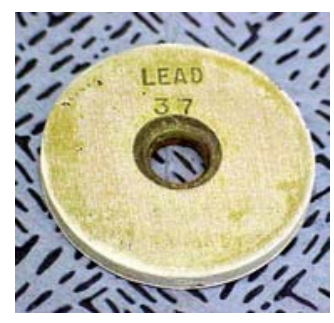

$\underline{\text { RTV }}$

\#43 (with water)

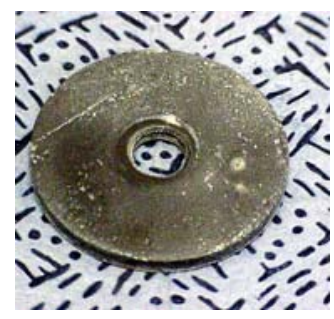

$\underline{\text { Celotex + Glue }}$

\#49 (with water)

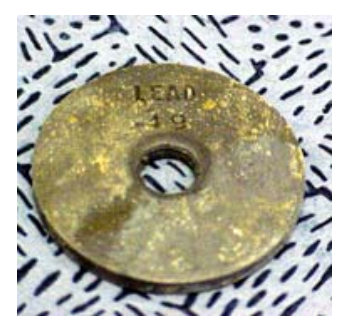

\#32 (w/o water)
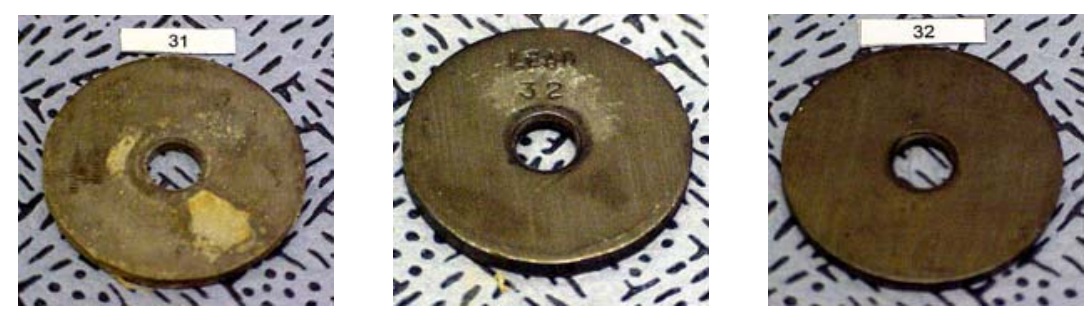

\#38 (w/o water)
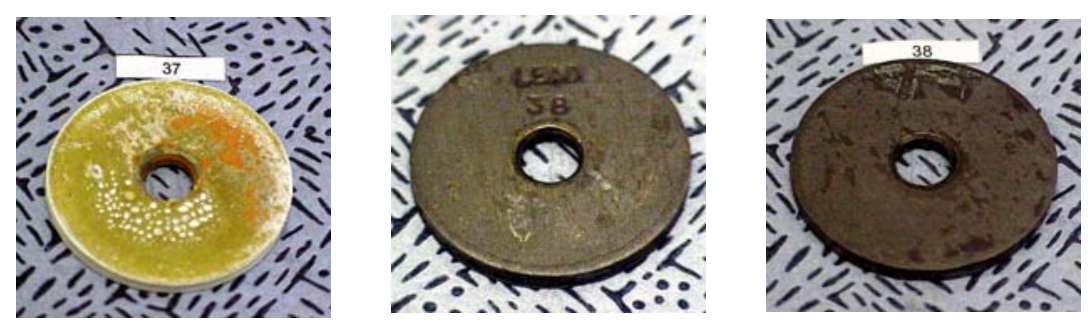

\#44 (w/o water)
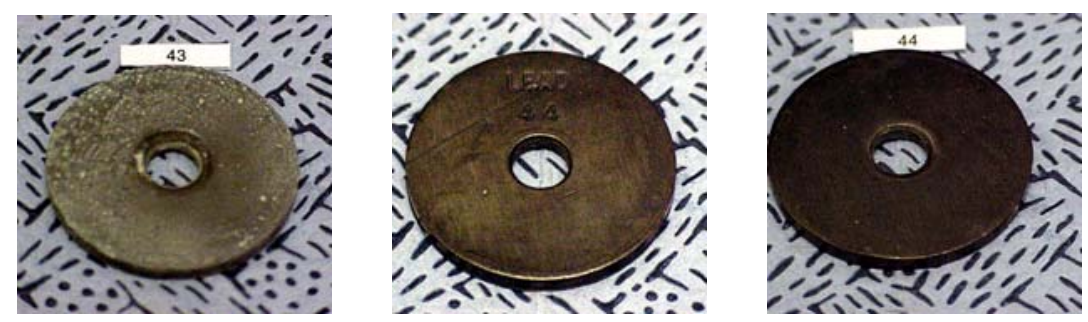

\#50 (w/o water)
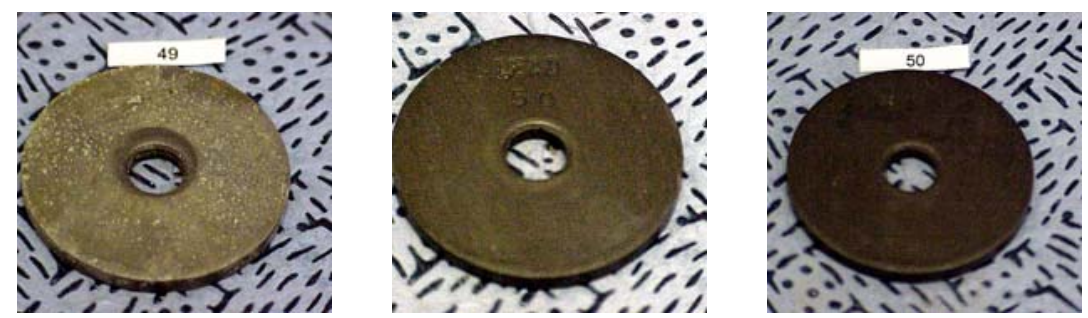
$\underline{\text { Celotex + Glue + RTV }}$

\#55 (with water)

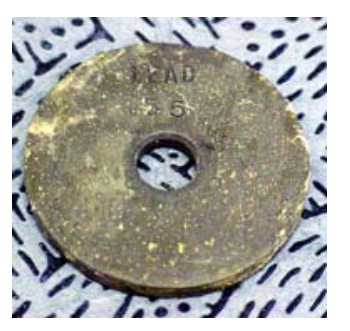

\#56 (w/o water)

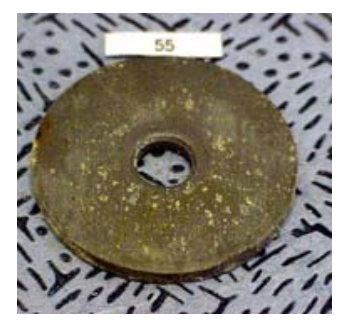

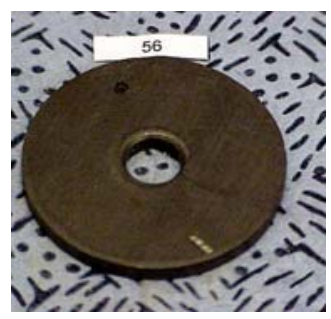

75 Day Coupons: $50^{\circ} \mathrm{C}$

$\underline{\text { Celotex }}$

\#35 (with water)

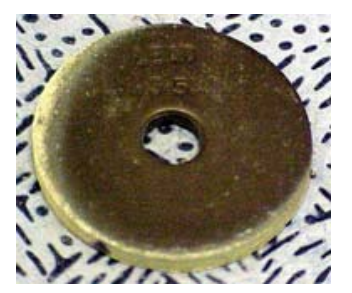

Glue

\#41 (w/water)

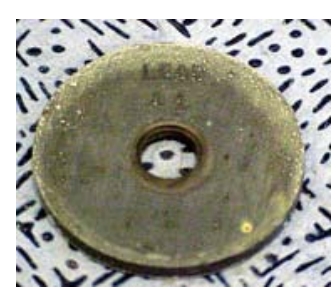

RTV

\#47 (with water)

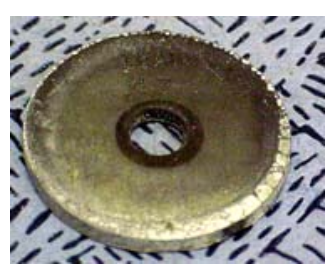

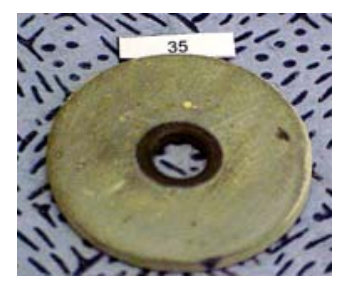
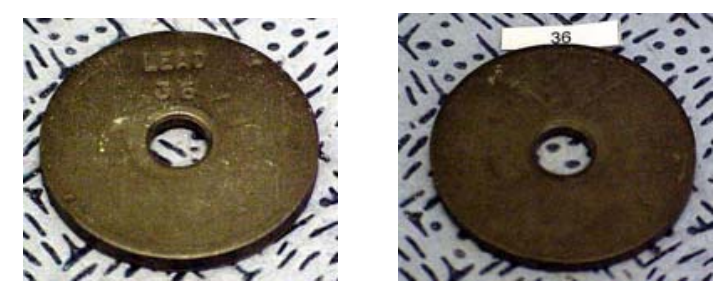

\#42 (w/o water)
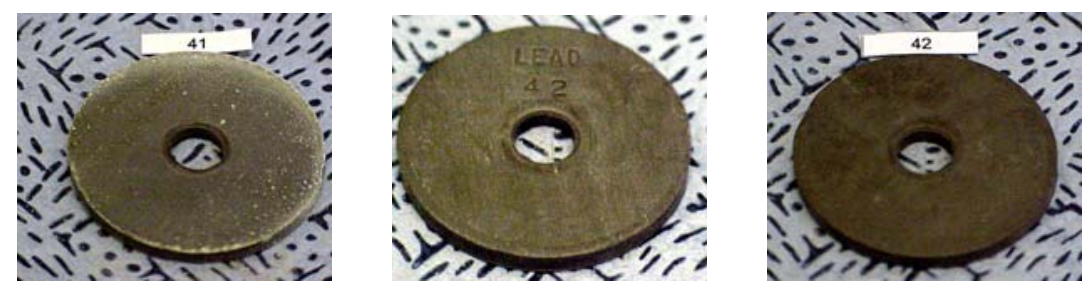

\#48 (w/o water)

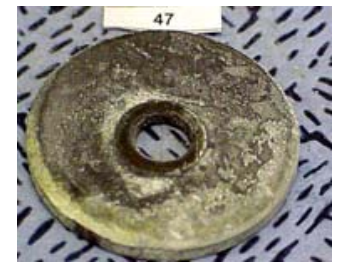

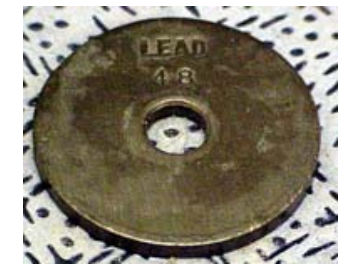


$\underline{\text { Celotex + Glue }}$

\#53 (with water)

\#54 (w/o water)
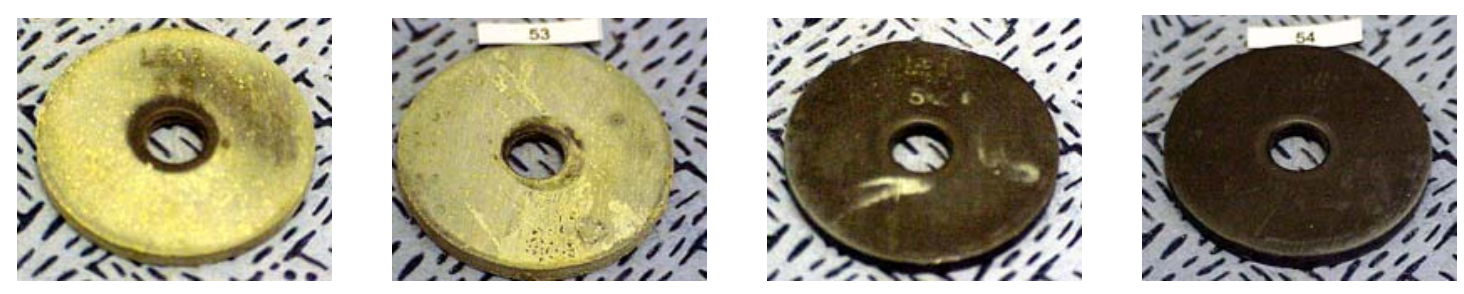

Celotex + Glue + RTV

\#59 (with water)

\#60 (w/o water)
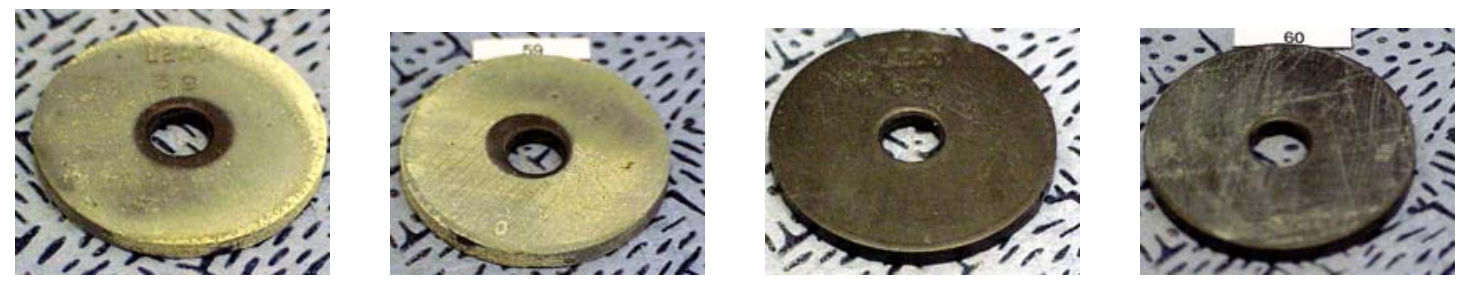

75 Day Coupons: $75^{\circ} \mathrm{C}$

$\underline{\text { Celotex }}$

\#33 (with water)

\#34 (w/o water)
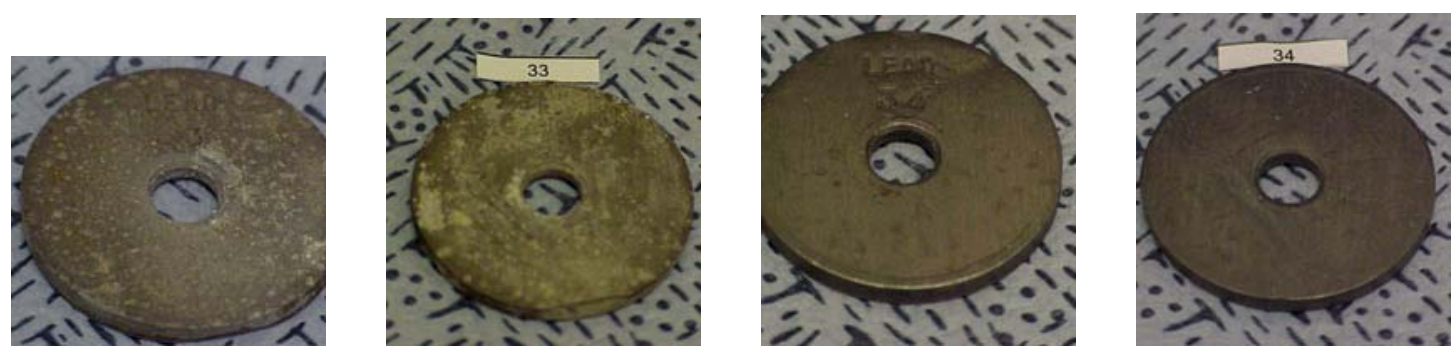

Glue

\#39 (with water)

\#40 (w/o water)
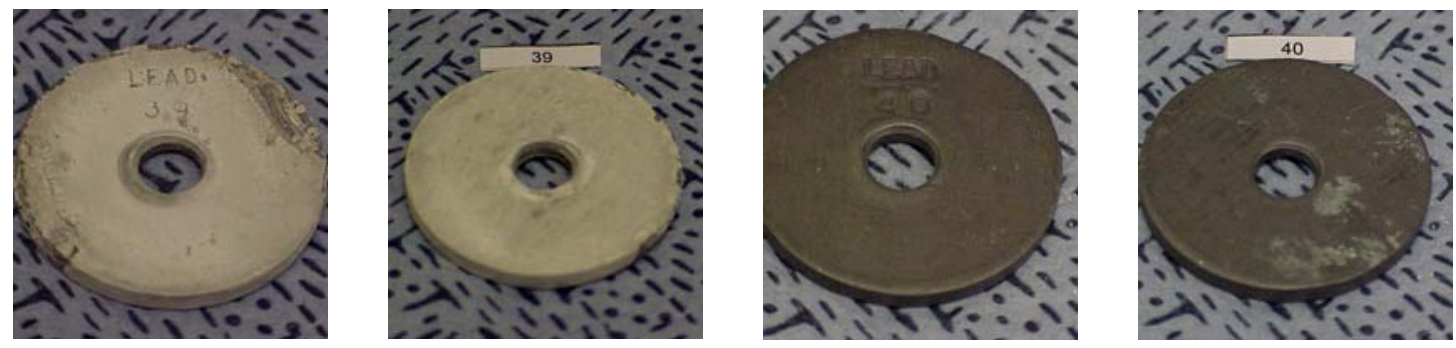
RTV

\#45 (with water)

\#46 (w/o water)
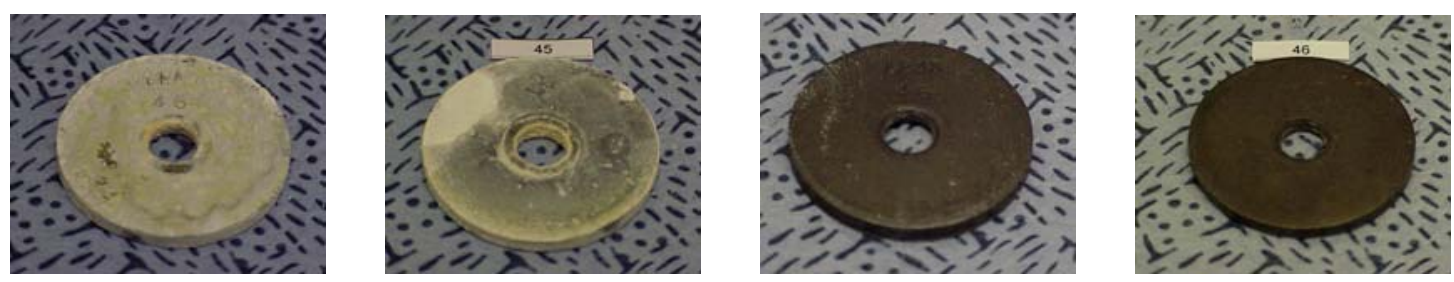

Celotex + Glue

\#51 (with water)

\#52 (w/o water)
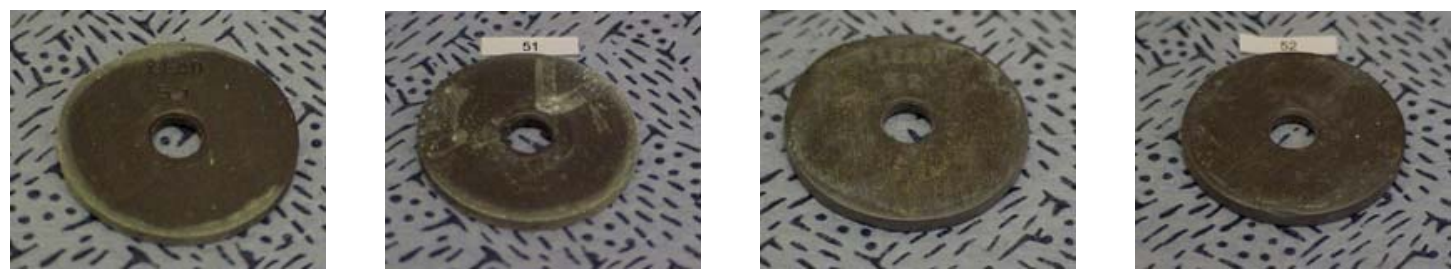

$\underline{\text { Celotex + Glue + RTV }}$

\#57 (with water)

\#58 (w/o water)
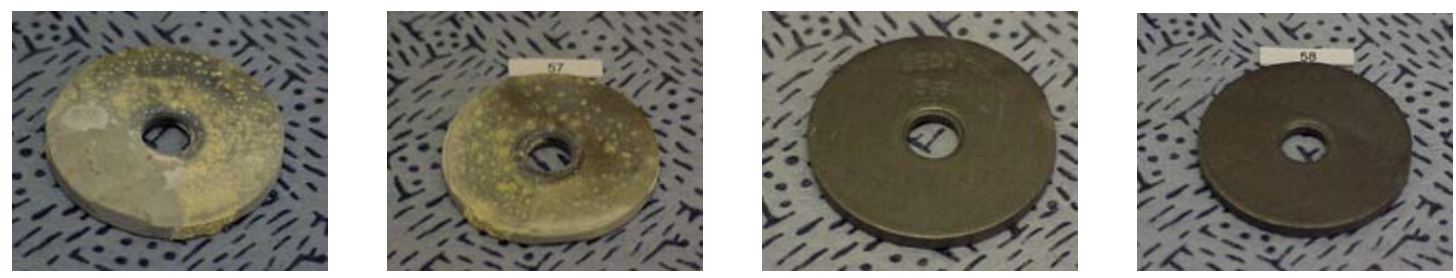
APPENDIX C: COUPONS AFTER 120 DAY EXPOSURE.

\section{Re-Exposed 30-Day Coupons: Room Temperature}

$\underline{\text { Celotex }}$

\#1 (w/water)

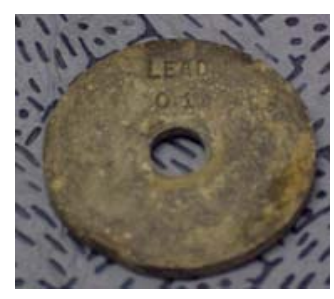

$\underline{\text { Glue }}$

\#7 (w/water)

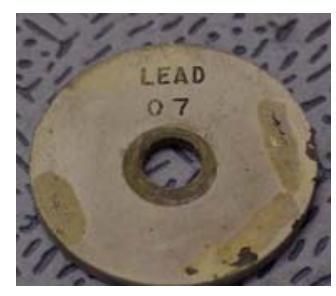

$\underline{\text { RTV }}$

\#13 (w/water)

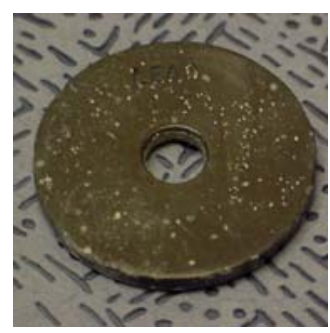

$\underline{\text { Celotex + Glue }}$

\#19 (w/water)

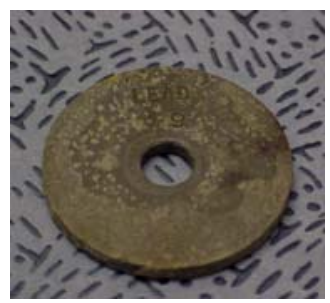

\#1 (w/water)

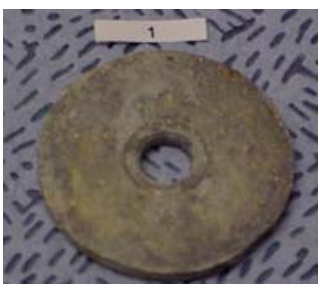

\#7 (w/water)

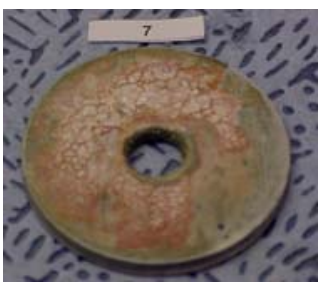

\#13 (w/water)

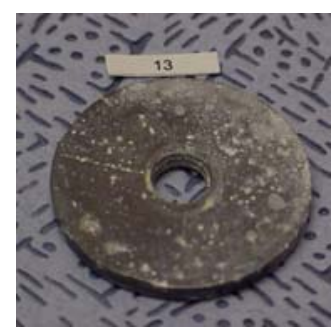

\#19 (w/water)

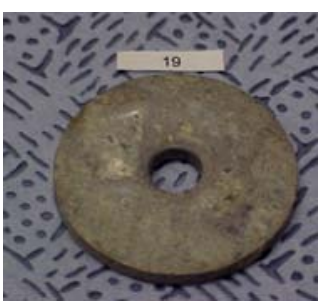

\#2 (w/o water)

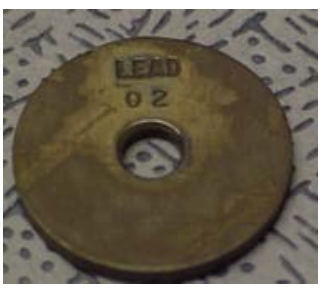

\#8 (w/o water)

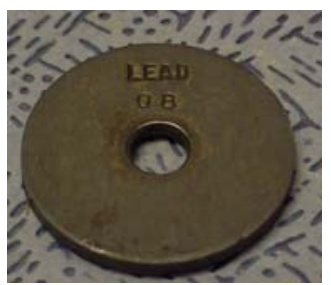

\#14 (w/o water)

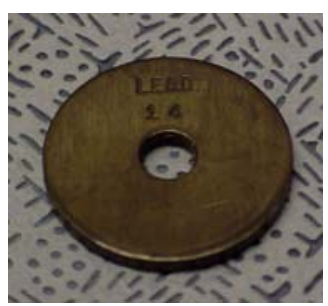

\#20 (w/o water)

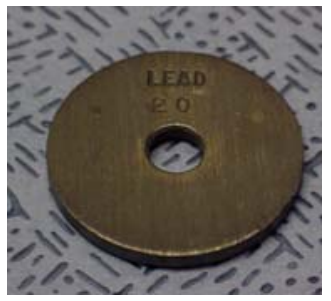

\#2 (w/o water)

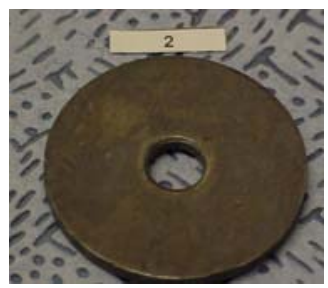

\#8 (w/o water)

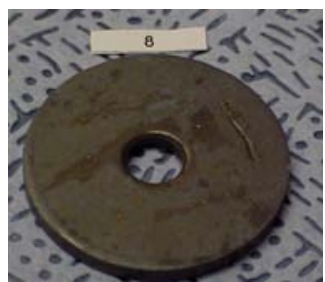

\#14 (w/o water)

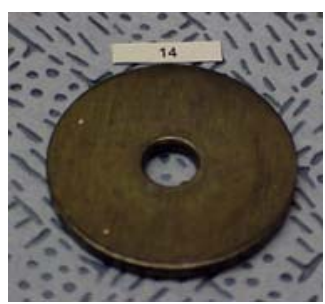

\#20 (w/o water)

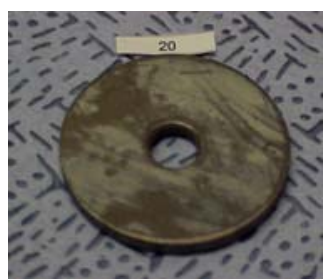


Celotex + Glue + RTV

\#25 (w/water)

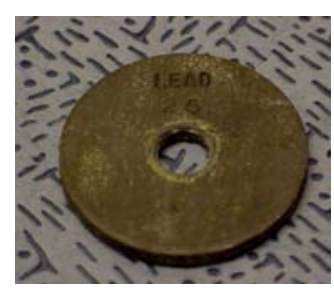

\#25 (w/water)

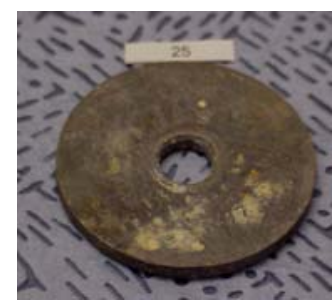

\#26 (w/o water)

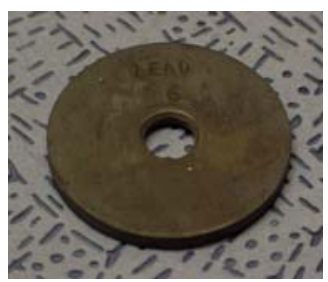

\#26 (w/o water)

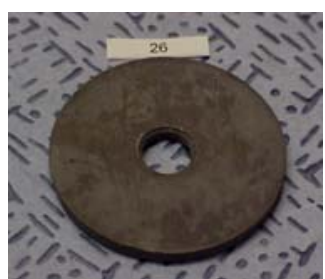

\section{Re-Exposed 75-Day Coupons: Room Temperature}

$\underline{\text { Celotex }}$

\#31 (w/water)

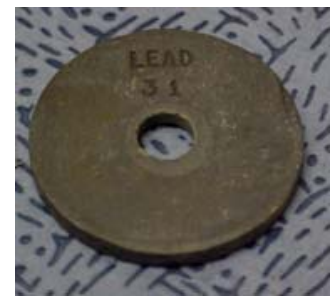

Glue

\#37 (w/water)

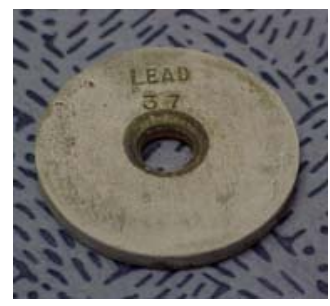

$\underline{\text { RTV }}$

\#43 (w/water)

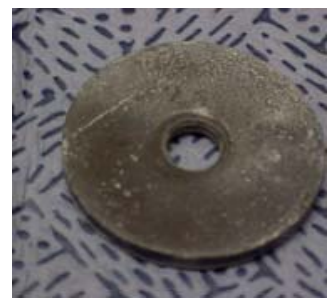

\#31 (w/water)

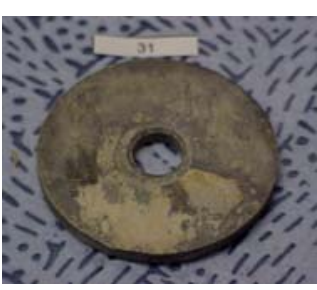

\#37 (w/water)

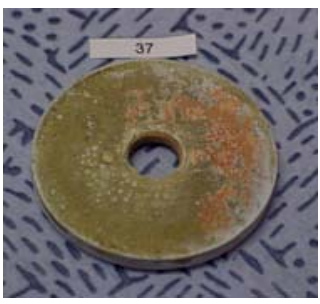

\#43 (w/water)

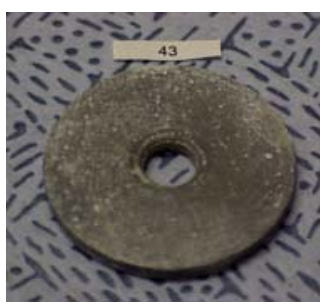

\#32 (w/o water)

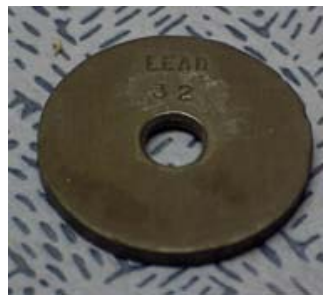

\#38 (w/o water)

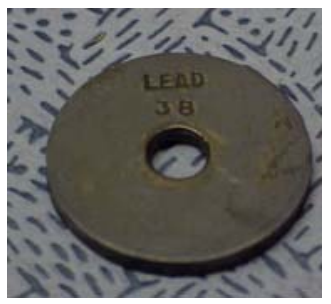

\#44 (w/o water)

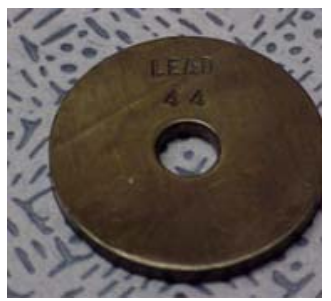

\#32 (w/o water)

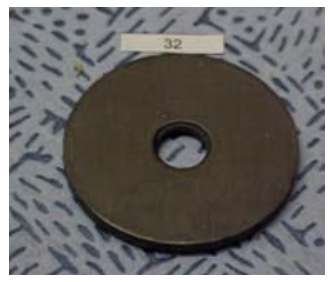

\#38 (w/o water)

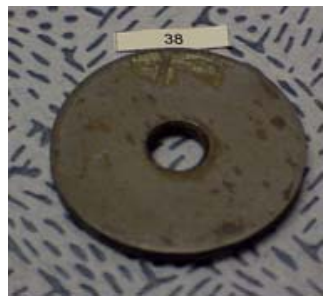

\#44 (w/o water)

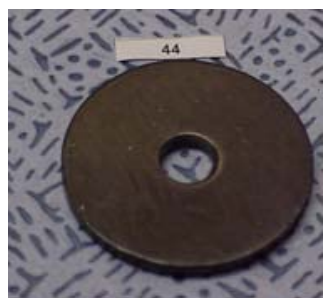




\section{Celotex + Glue}

\#49 (w/water)

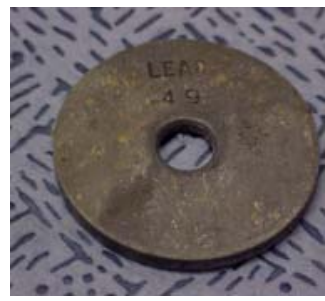

$\underline{\text { Celotex + Glue + RTV }}$

\#55 (w/water)

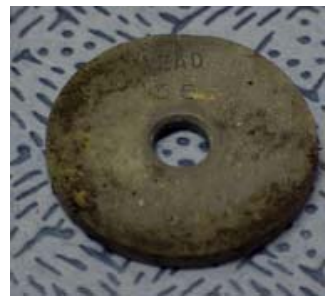

\#49 (w/water)

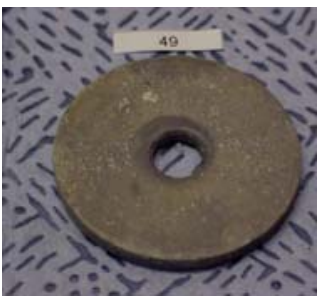

\#55 (w/water)

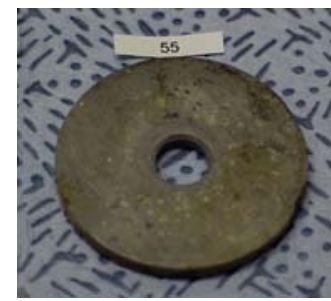

\#50 (w/o water)

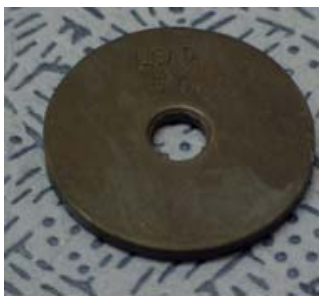

\#56 (w/o water)

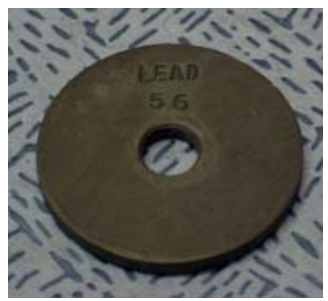

\#50 (w/o water)

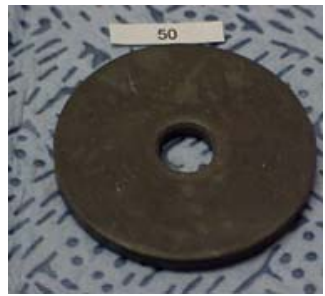

\#56 (w/o water)

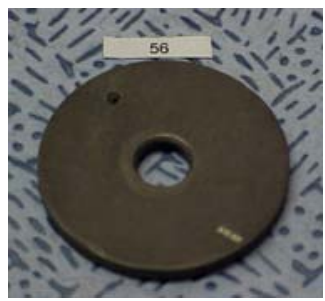

120 Day Coupons: Room Temperature

$\underline{\text { Celotex }}$

\#61 (w/water)

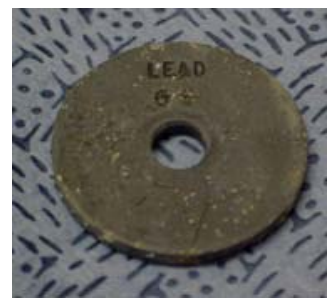

Glue

\#67 (w/water)

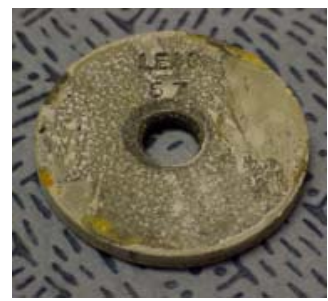

\#61 (w/water)

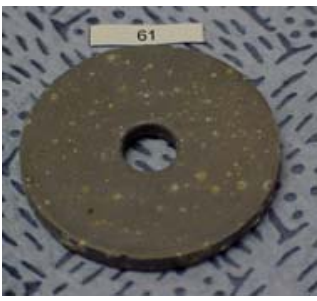

\#67 (w/water)

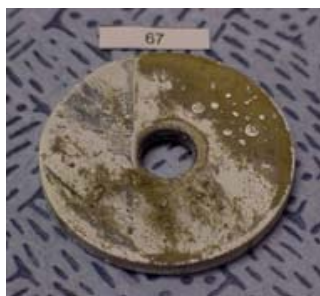

\#62 (w/o water)

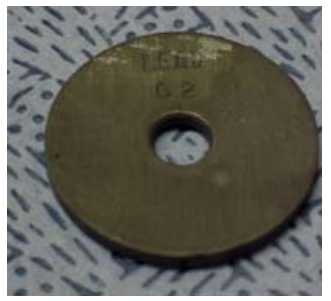

\#68 (w/o water)

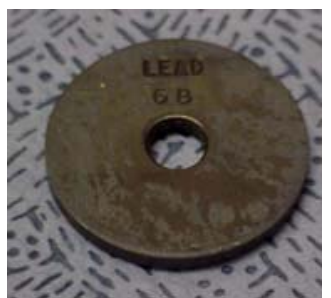

\#62 (w/o water)

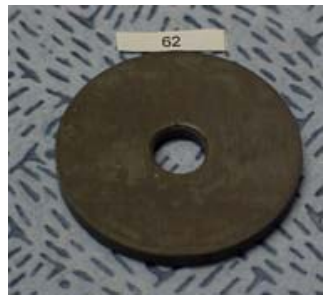

\#68 (w/o water)

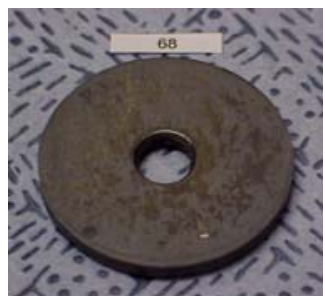


$\underline{\text { RTV }}$

\#73 (w/water)

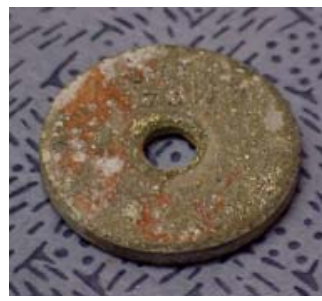

$\underline{\text { Celotex }+ \text { Glue }}$

\#79 (w/water)

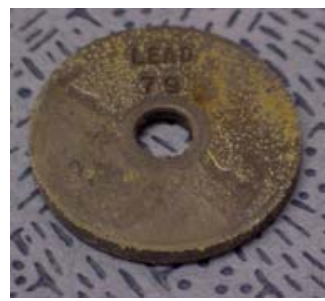

$\underline{\text { Celotex + Glue + RTV }}$

\#85 (w/water)

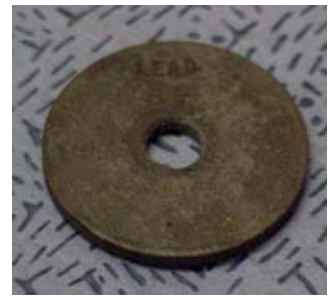

\#73 (w/water)

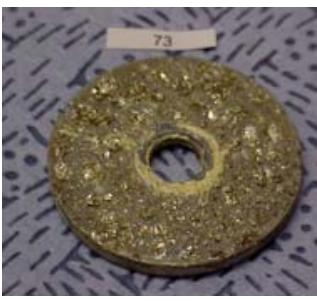

\#79 (w/water)

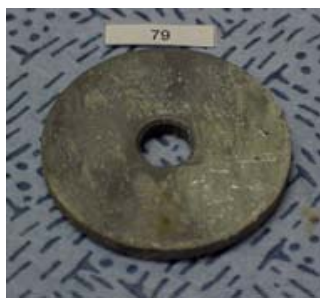

\#85 (w/water)

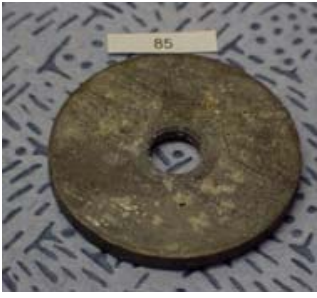

\#74 (w/o water)

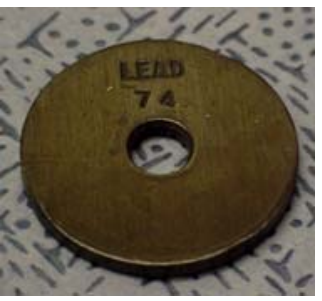

\#80 (w/o water)

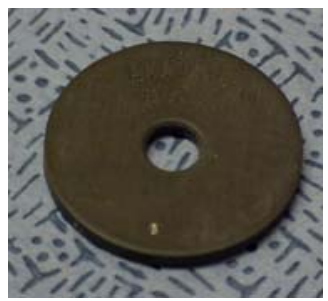

\#86 (w/o water)

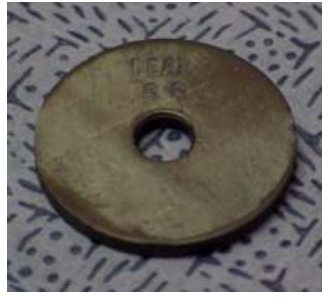

\#74 (w/o water)

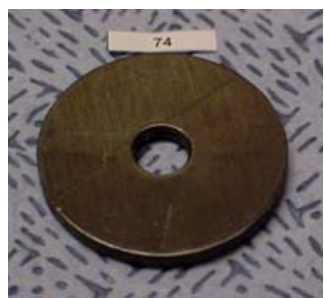

\#80 (w/o water)

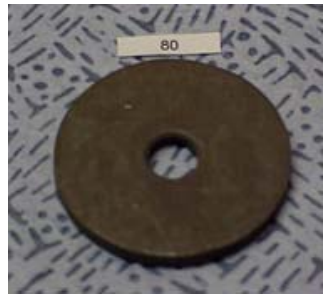

\#86 (w/o water)

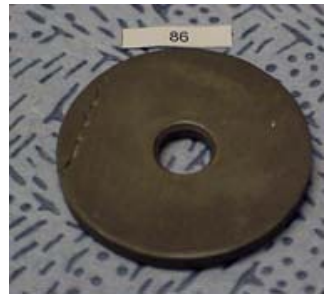

Re-Exposed 30-day Coupons: $50^{\circ} \mathrm{C}$

$\underline{\text { Celotex }}$

\#3 (w/water)

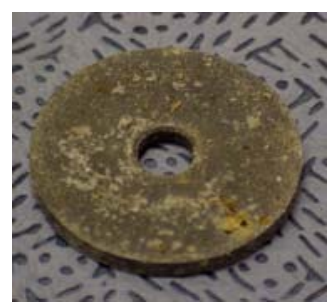

\#3 (w/water)

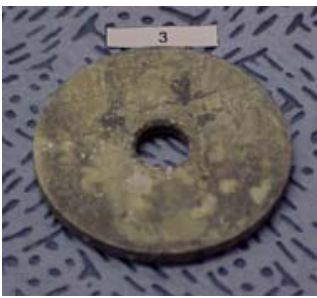

\#4 (w/o water)

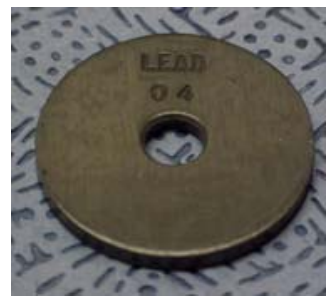

\#4 (w/o water)

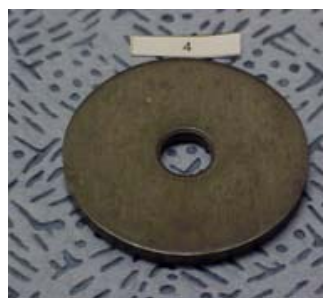


Glue

\#9 (w/water)

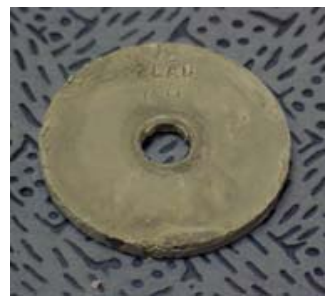

$\underline{\text { RTV }}$

\#15 (w/water)

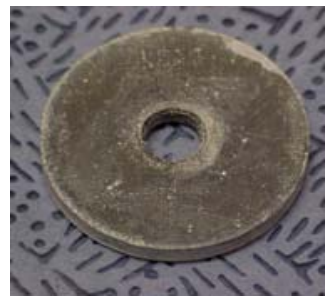

$\underline{\text { Celotex + Glue }}$

\#21 (w/water)

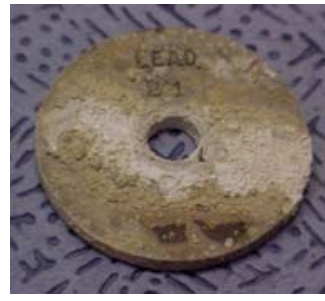

$\underline{\text { Celotex + Glue + RTV }}$

\#27 (w/water)

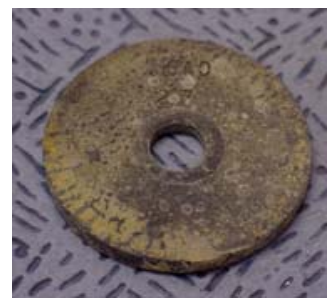

\#9 (w/water)

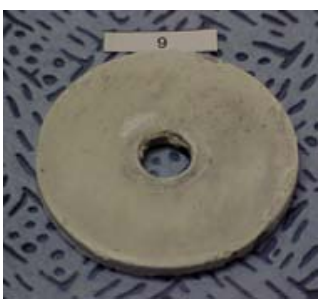

\#15 (w/water)

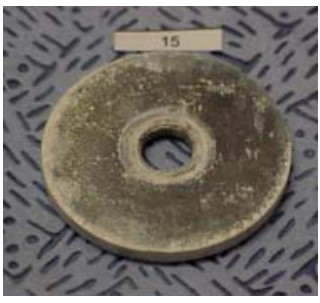

\#21 (w/water)

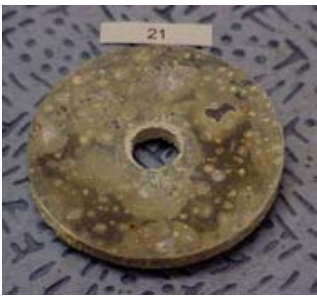

\#27 (w/water)

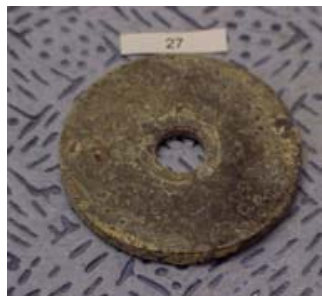

\#10 (w/o water)

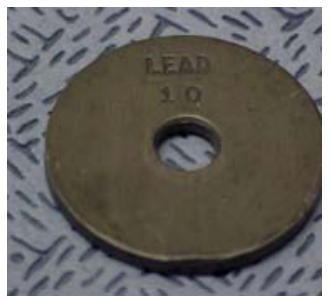

\#16 (w/o water)

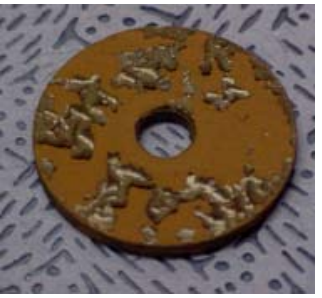

\#22 (w/o water)

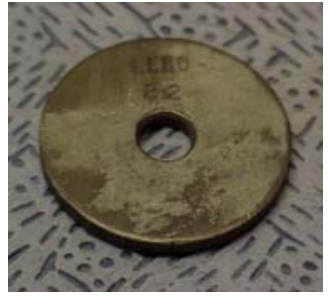

\#28 (w/o water)

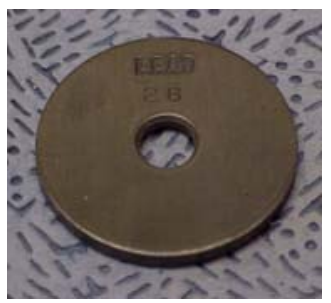

\#10 (w/o water)

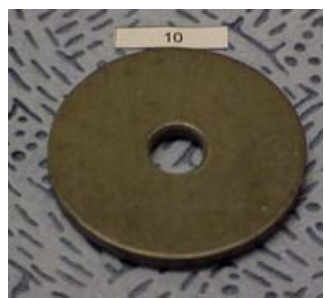

\#16 (w/o water)

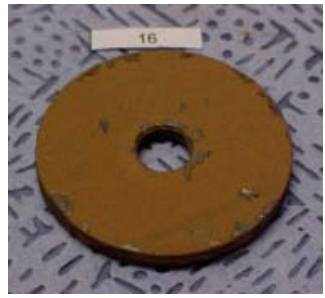

\#22 (w/o water)

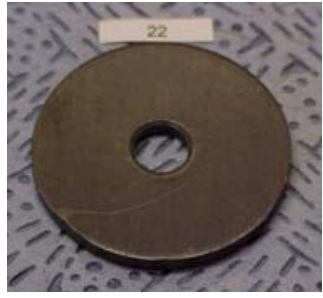

\#28 (w/o water)

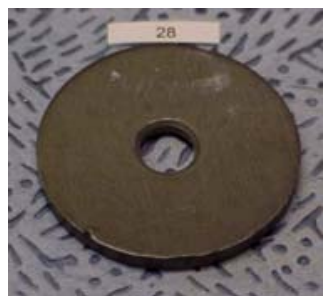


Re-Exposed 75-Day Coupons: 50 $^{\circ} \mathrm{C}$

$\underline{\text { Celotex }}$

33 (w/water)

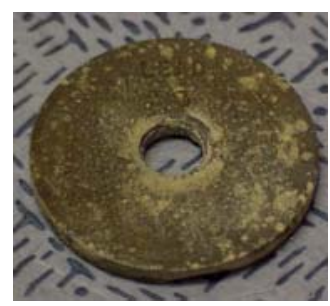

$\underline{\text { Glue }}$

\#39 (w/water)

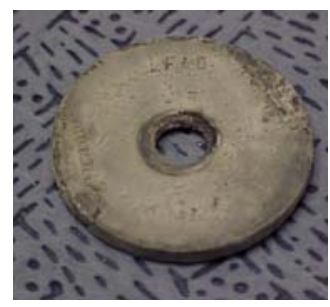

$\underline{\text { RTV }}$

\#45 (w/water)

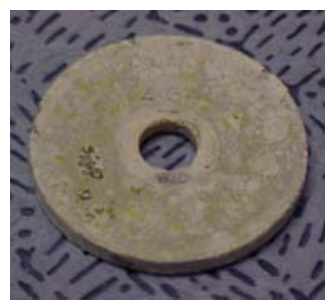

$\underline{\text { Celotex + Glue }}$

\#51 (w/water)

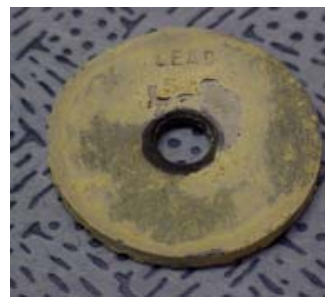

\#33 (w/water)

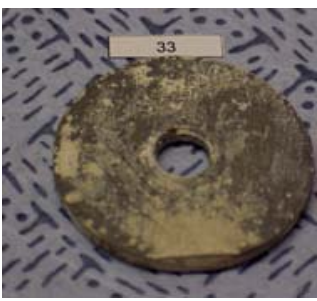

\#39 (w/water)

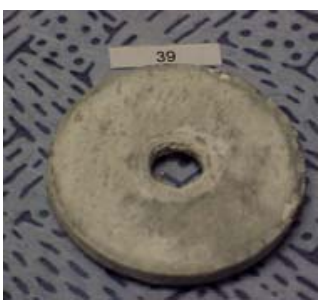

\#45 (w/water)

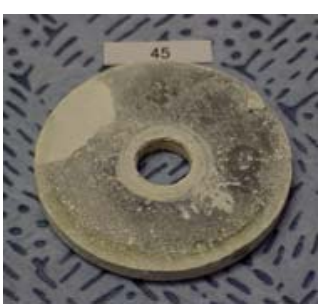

\#51 (w/water)

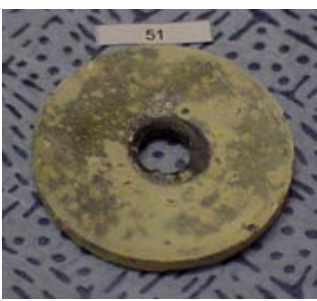

\#34 (w/o water)

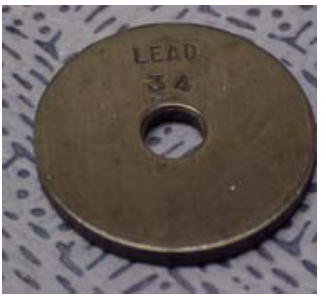

\#40 (w/o water)

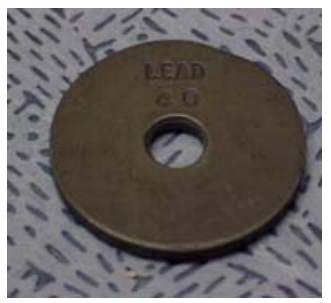

\#46 (w/o water)

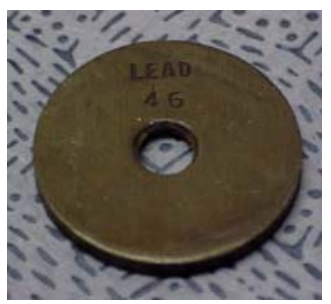

\#52 (w/o water)

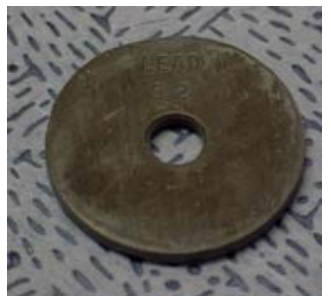

\#34 (w/o water)

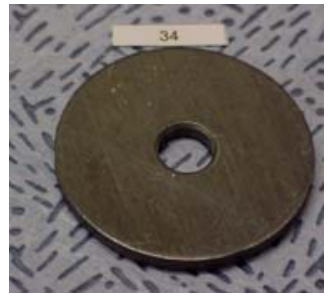

\#40 (w/o water))

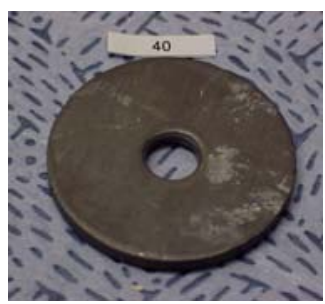

\#46 (w/o water)

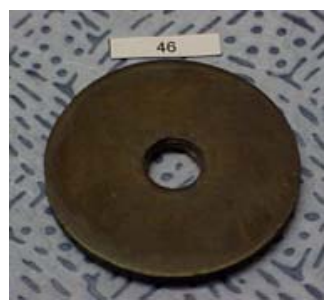

\#52 (w/o water)

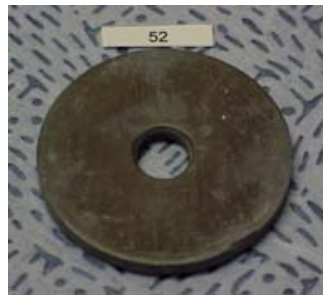


$\underline{\text { Celotex + Glue + RTV }}$

\#57 (w/water)

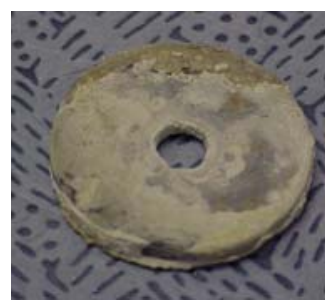

\#57 (w/water)

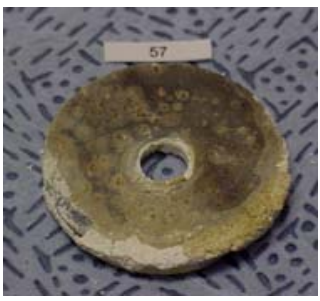

\#58 (w/o water)

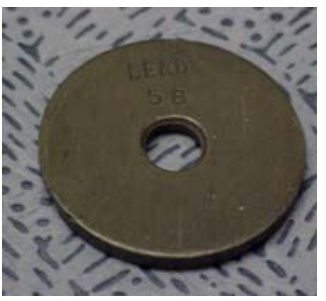

\#58 (w/o water)

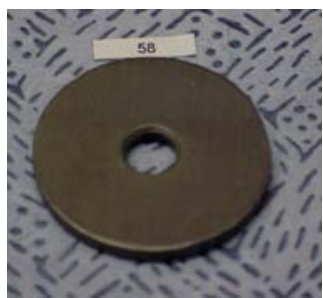

120 Day Coupons: $50^{\circ} \mathrm{C}$

$\underline{\text { Celotex }}$

\#63 (w/water)

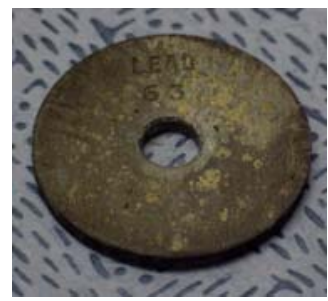

Glue

\#69 (w/water)

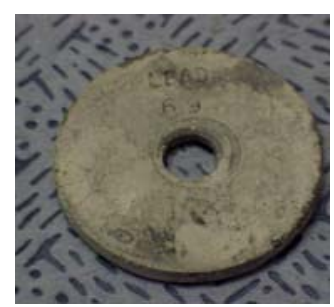

$\underline{\text { RTV }}$

\#75 (w/water)

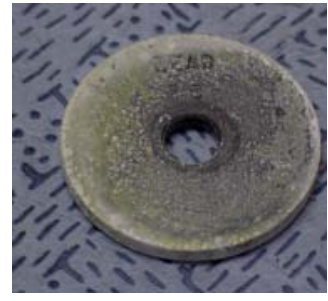

\#63 (w/water)

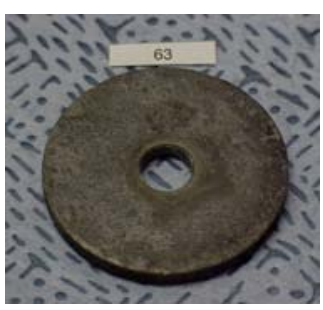

\#69 (w/water)

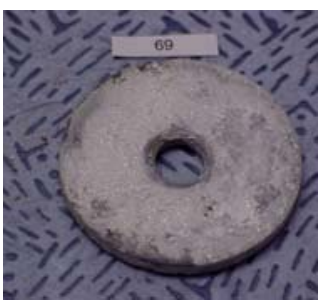

\#75 (w/water)

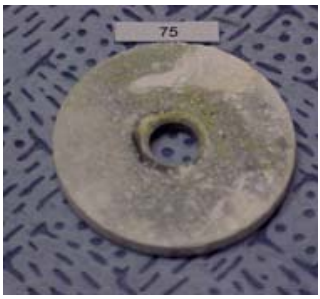

\#64 (w/o water)

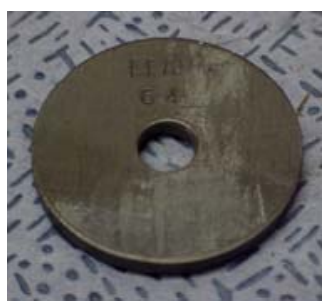

\#70 (w/o water)

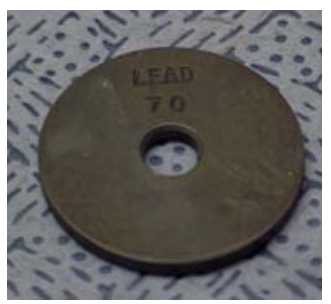

\#76 (w/o water)

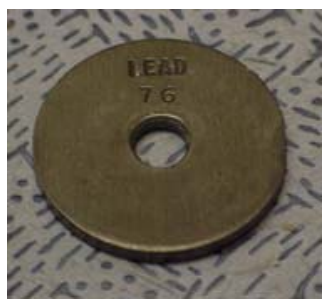

\#64 (w/o water)

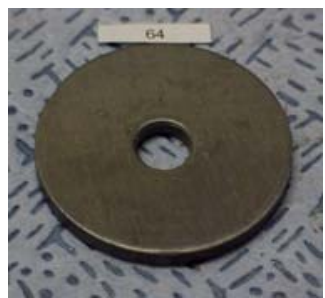

\#70 (w/o water)

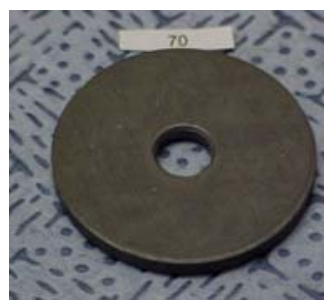

\#76 (w/o water)

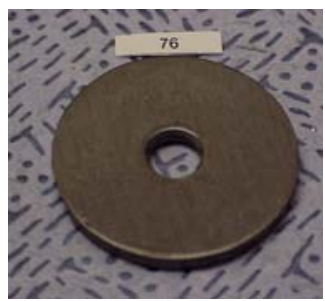




\section{Celotex + Glue}

\#81 (w/water)

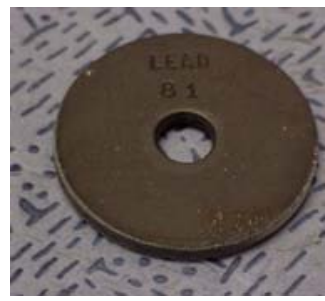

$\underline{\text { Celotex + Glue + RTV }}$

\#87 (w/water)

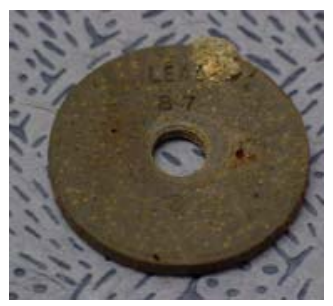

\#81 (w/water)

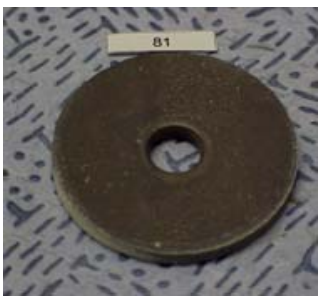

\#87 (w/water)

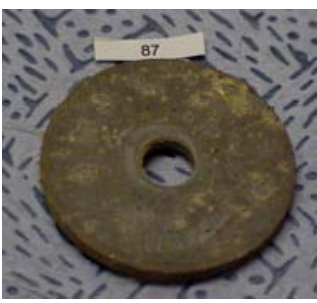

\#82 (w/o water)

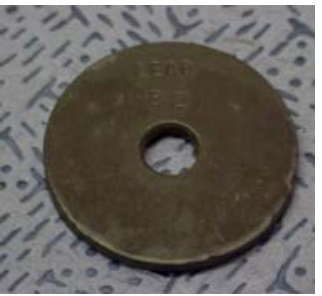

\#88 (w/o water)

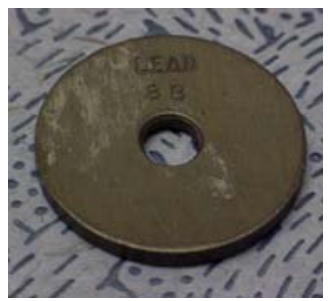

\#82 (w/o water)

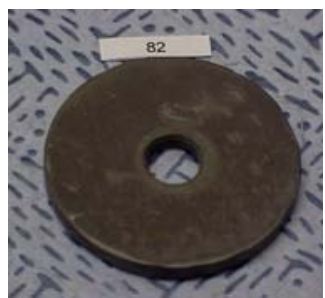

\#88 (w/o water)

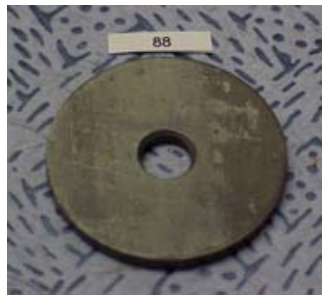

\section{Re-Exposed 30 Day Coupons: $75^{\circ} \mathrm{C}$}

$\underline{\text { Celotex }}$

\#5 (w/water)

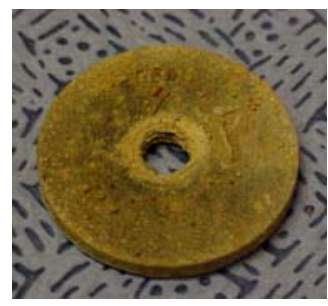

Glue

\#11 (w/water)

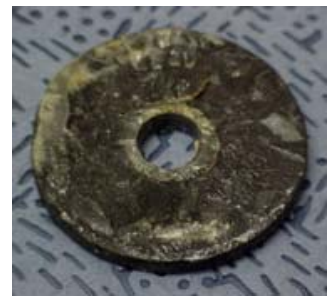

\#5 (w/water)

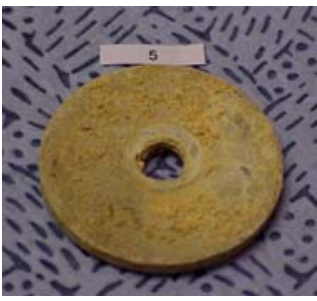

\#11 (w/water)

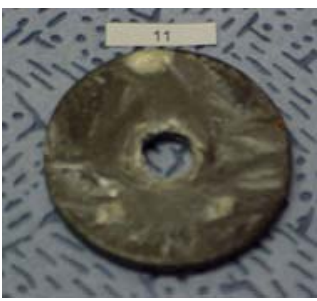

\#6 (w/o water)

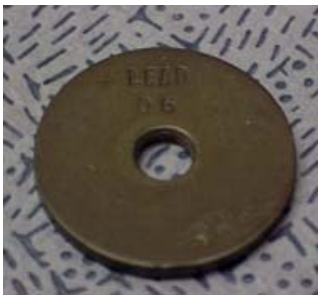

\#12 (w/o water)

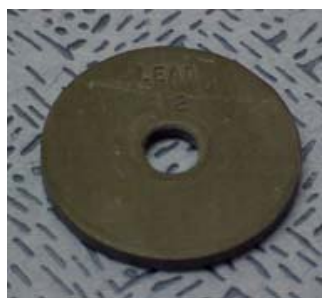

\#6 (w/o water)

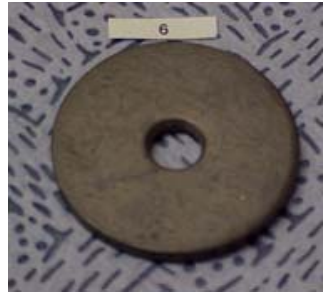

\#12 (w/o water)

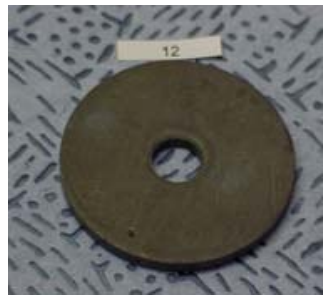


$\underline{\text { RTV }}$

\#17 (w/water)

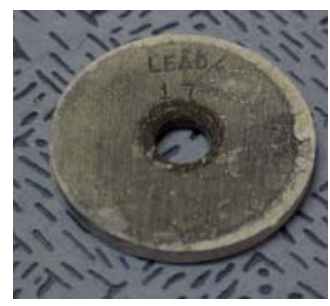

$\underline{\text { Celotex }+ \text { Glue }}$

\#23 (w/water)

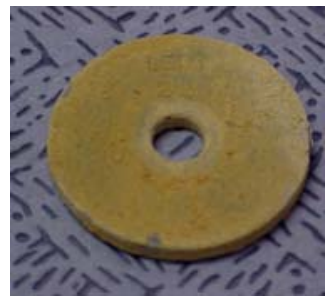

$\underline{\text { Celotex + Glue + RTV }}$

\#29 (w/water)

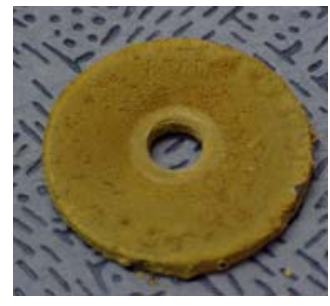

\#17 (w/water)

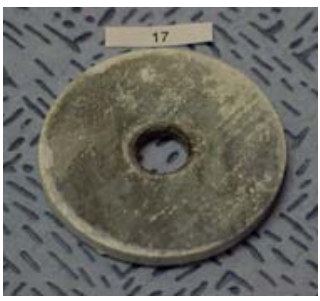

\#23 (w/water)

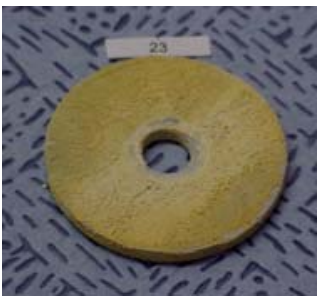

\#29 (w/water)

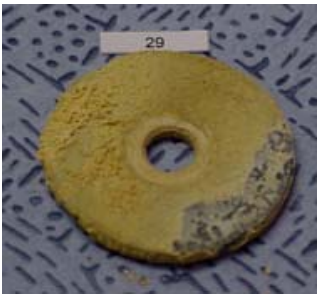

\#18 (w/o water)

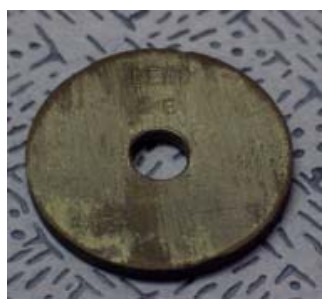

\#24 (w/o water)

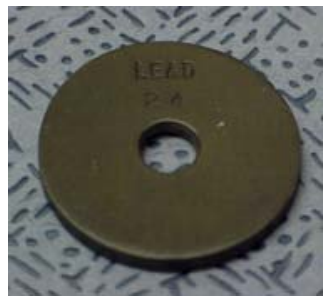

\#30 (w/o water)

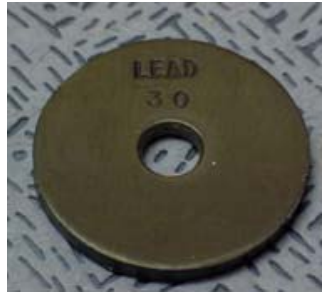

\#18 (w/o water)

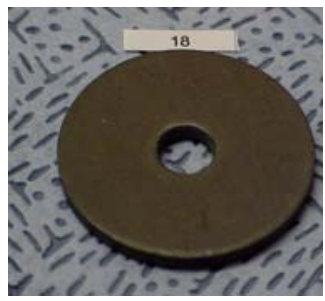

\#24 (w/o water)

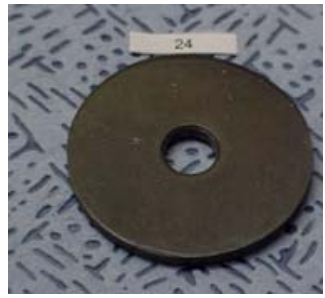

\#30 (w/o water)

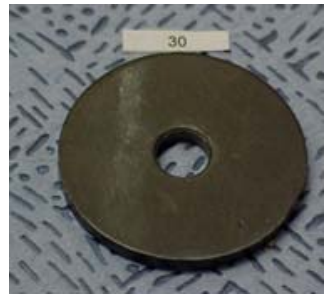

Re-Exposed 75-Day Coupons: $75^{\circ} \mathrm{C}$

$\underline{\text { Celotex }}$
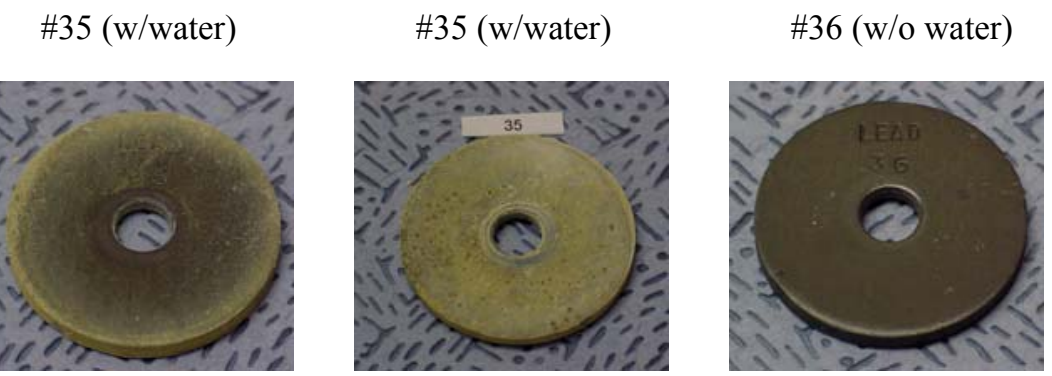

\#36 (w/o water)

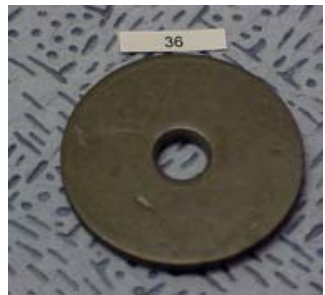


Glue

\#41 (w/water)

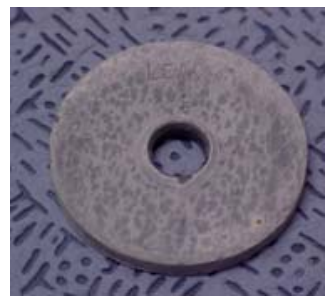

$\underline{\mathrm{RTV}}$

\#47 (w/water)

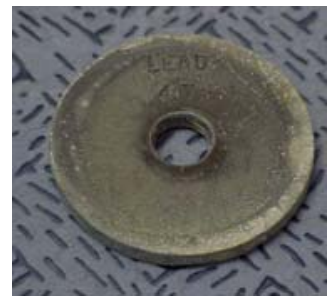

$\underline{\text { Celotex + Glue }}$

\#53 (w/water)

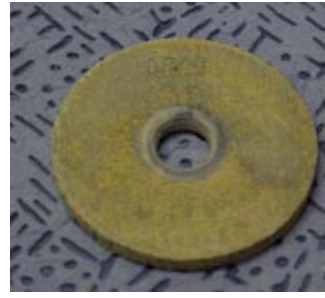

$\underline{\text { Celotex + Glue + RTV }}$

\#59 (w/water)

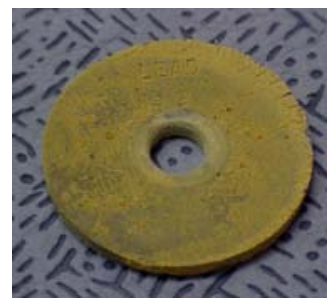

\#41 (w/water)

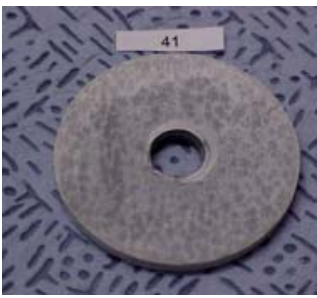

\#47 (w/water)

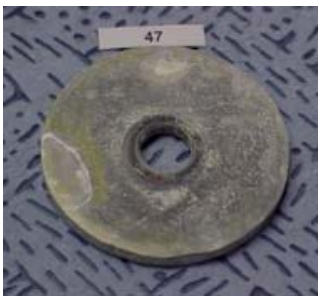

\#53 (w/water)

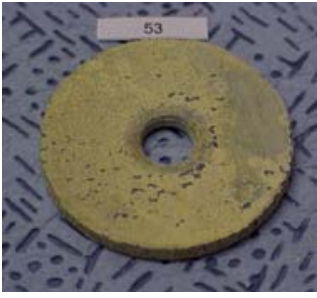

\#59 (w/water)

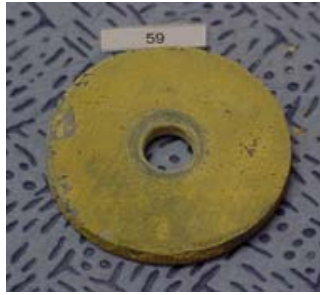

\#42 (w/o water)

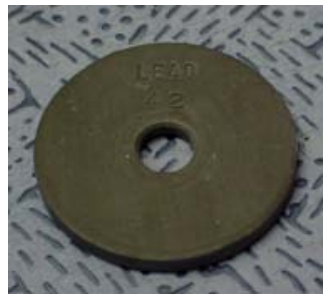

\#48 (w/o water)

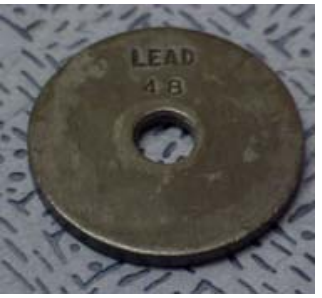

\#54 (w/o water)

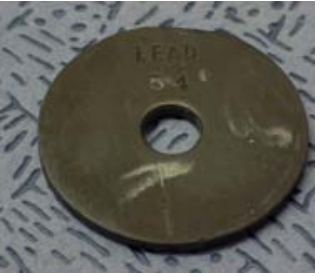

\#60 (w/o water)

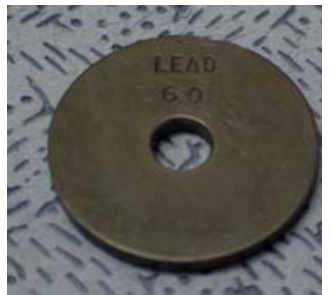

\#42 (w/o water)

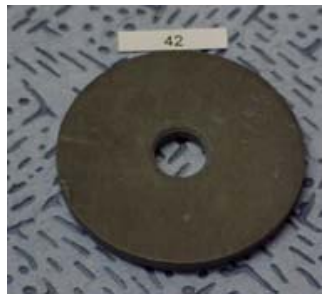

\#48 (w/o water)

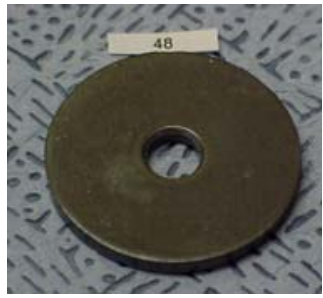

\#54 (w/o water)

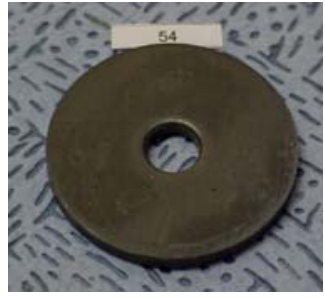

\#60 (w/o water)

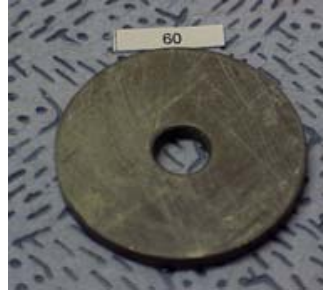


120 Day Coupons: $75^{\circ} \mathrm{C}$

$\underline{\text { Celotex }}$
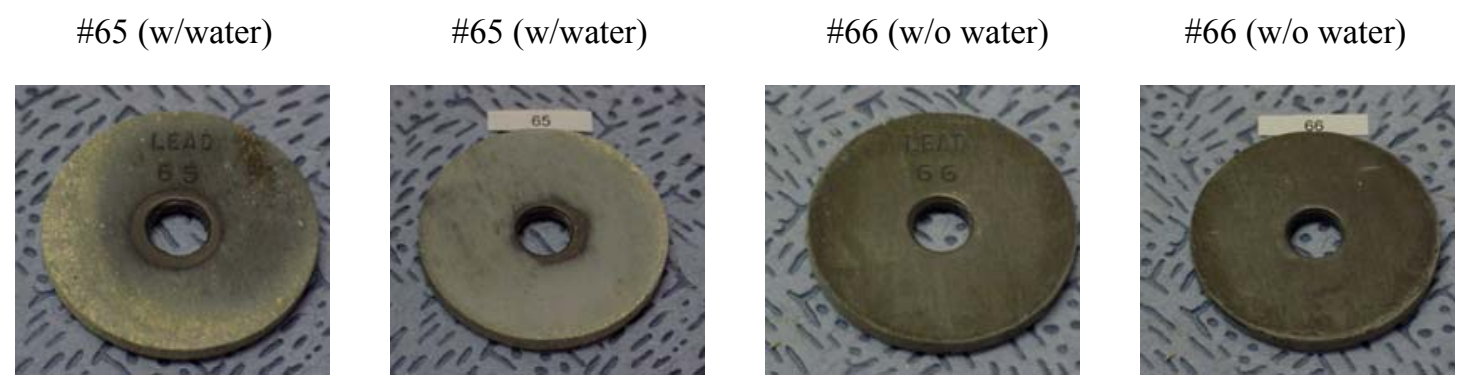

Glue

\#71 (w/water)

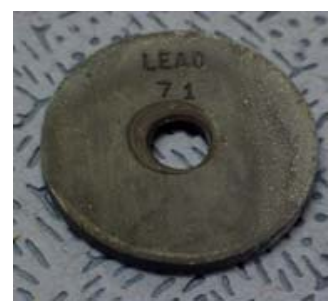

$\underline{\text { RTV }}$

\#77 (w/water)

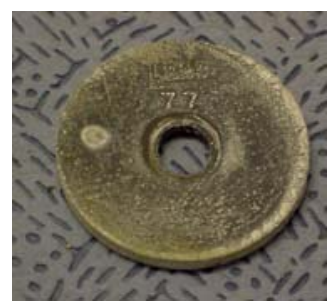

$\underline{\text { Celotex + Glue }}$

\#83 (w/water)

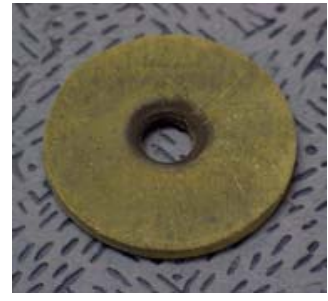

\#71 (w/water)

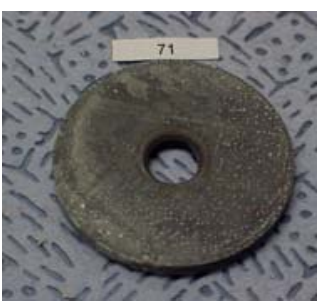

\#77 (w/water)

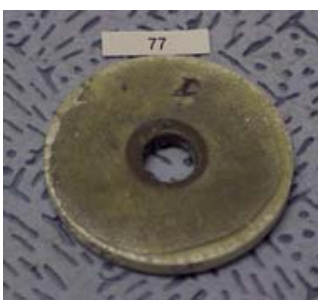

\#83 (w/water)

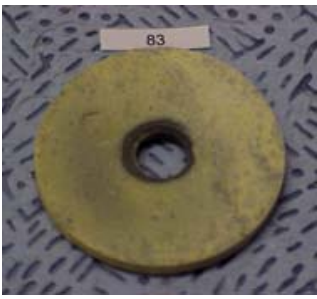

\#72 (w/o water)

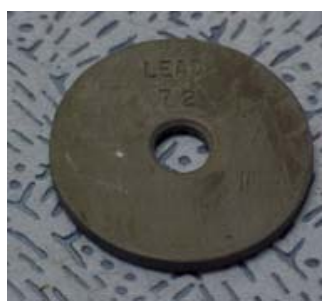

\#78 (w/o water)

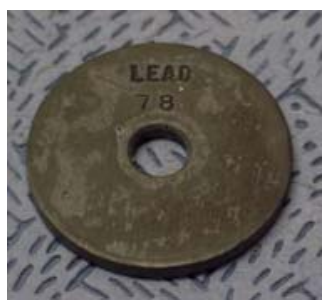

\#84 (w/o water)

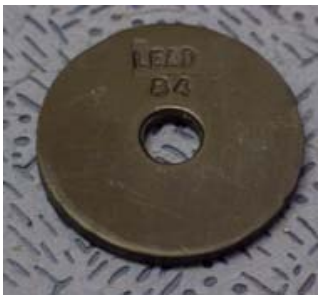

\#72 (w/o water)

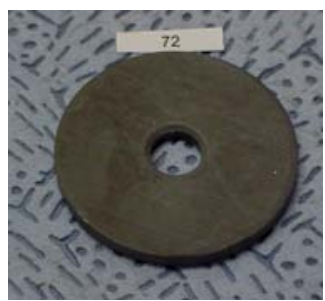

\#78 (w/o water)

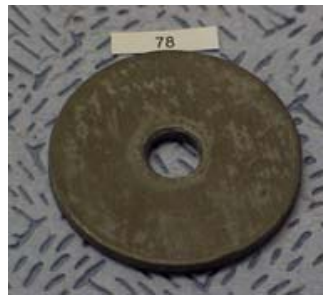

\#84 (w/o water)

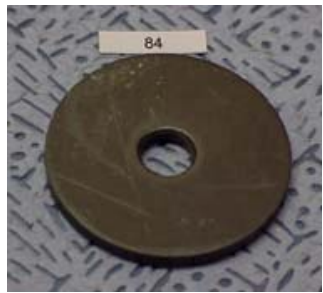




\section{$\underline{\text { Celotex + Glue + RTV }}$}

\#89 (w/water)

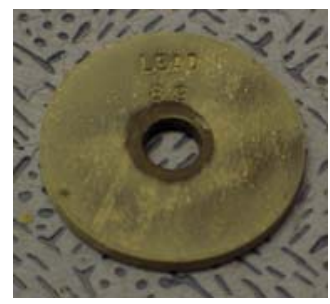

\#89 (w/water)

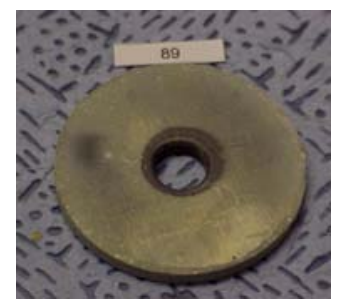

\#90 (w/o water)

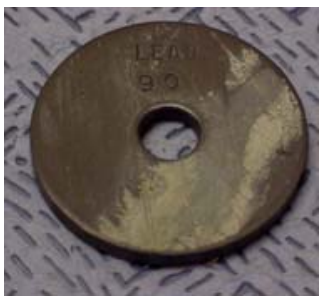

\#90 (w/o water)

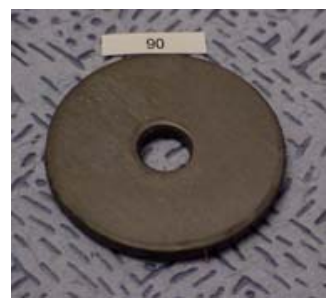

